\title{
Precision surgery and genitourinary cancers
}

\author{
R. Autorino ${ }^{\mathrm{a}, *}$, F. Porpiglia $^{\mathrm{b}}$, P. Dasgupta ${ }^{\mathrm{c}}$, J. Rassweiler ${ }^{\mathrm{d}}$, \\ J.W. Catto ${ }^{\mathrm{e}}$, L.J. Hampton ${ }^{\mathrm{f}}$, E. Lima ${ }^{\mathrm{g}}$, V. Mirone ${ }^{\text {h }}$, I.H. Derweesh ${ }^{\mathrm{i}}$, \\ F.M.J. Debruyne ${ }^{j}$ \\ ${ }^{a}$ Urology Institute, University Hospitals, Case Western Reserve University, Cleveland, OH, USA \\ ${ }^{\mathrm{b}}$ Division of Urology, University of Turin, San Luigi Hospital, Orbassano, Italy \\ ${ }^{\mathrm{c}}$ King's College London, Guy's Hospital, London, UK \\ ${ }^{\mathrm{d}}$ Department of Urology, SLK Kliniken Heilbronn, University of Heidelberg, Heidelberg, Germany \\ ${ }^{\mathrm{e}}$ Academic Urology Unit, University of Sheffield, Sheffield, UK \\ ${ }^{\mathrm{f}}$ Division of Urology, Virginia Commonwealth University, Richmond, VA, USA \\ ${ }^{\mathrm{g}}$ Life and Health Sciences Research Institute, The Clinic Academic Center, University of Minho, and \\ Department of CUF Urology, Braga, Portugal \\ ${ }^{\mathrm{h}}$ Department of Urology, Federico II University, Naples, Italy \\ ${ }^{i}$ Department of Urology, UC San Diego Health System, La Jolla, CA, USA \\ ${ }^{\mathrm{j}}$ Andros Men's Health Institutes, Arnhem, The Netherlands
}

Accepted 8 February 2017

Available online 20 February 2017

\begin{abstract}
The landscape of the surgical management of urologic malignancies has dramatically changed over the past 20 years. On one side, better diagnostic and prognostic tools allowed better patient selection and more reliable surgical planning. On the other hand, the implementation of minimally invasive techniques and technologies, such as robot-assisted laparoscopy surgery and image-guided surgery, allowed minimizing surgical morbidity. Ultimately, these advances have translated into a more tailored approach to the management of urologic cancer patients. Following the paradigm of "precision medicine", contemporary urologic surgery has entered a technology-driven era of "precision surgery", which entails a range of surgical procedures tailored to combine maximal treatment efficacy with minimal impact on patient function and health related quality of life. Aim of this non-systematic review is to provide a critical analysis of the most recent advances in the field of surgical uro-oncology, and to define the current and future role of "precision surgery" in the management of genitourinary cancers. (C) 2017 Elsevier Ltd, BASO The Association for Cancer Surgery, and the European Society of Surgical Oncology. All rights reserved.
\end{abstract}

Keywords: Precision surgery; Uro-oncology; Genitourinary cancer; Prostate cancer; Bladder cancer; Kidney cancer; Robotic surgery

\section{Introduction}

The landscape of the surgical management of urologic malignancies has dramatically changed over the past 20 years. On one side, better diagnostic and prognostic tools

\footnotetext{
* Corresponding author. Fax: +1 2162015276.

E-mail addresses: ricautor@gmail.com (R. Autorino), porpiglia@ libero.it (F. Porpiglia), prokarurol@gmail.com (P. Dasgupta), jens.rassweiler@slk-kliniken.de (J. Rassweiler), j.catto@sheffield.ac.uk (J.W. Catto), lance.hampton@vcuhealth.org (L.J. Hampton), estevaolima@ecsaude.uminho.pt (E. Lima), mirone@unina.it (V. Mirone), iderweesh@gmail.com (I.H. Derweesh), f.debruyne@ uroweb.org (F.M.J. Debruyne).
}

allowed better patient selection and more reliable surgical planning. On the other hand, the implementation of minimally invasive techniques and technologies, such as robot-assisted laparoscopy surgery and image-guided surgery, allowed minimizing surgical morbidity. Ultimately, these advances have translated into a more tailored approach to the management of urologic cancer patients. Following the paradigm of "precision medicine", contemporary urologic surgery has entered a technology-driven era of "precision surgery", which entails a range of surgical procedures tailored to combine maximal treatment efficacy with minimal impact on patient function and health related quality of life. ${ }^{1}$ The aim of this non-systematic review is to 
provide a critical analysis of the most recent advances in the field of surgical uro-oncology, and to define the current and future role of "precision surgery" in the management of genitourinary cancers, with a focus on prostate, bladder and kidney cancer.

\section{Prostate cancer}

Prostate cancer continues to have a high incidence in most industrialized countries, despite decreasing mortality rates. ${ }^{2}$ Standardization in multi-parametric MRI techniques allowed better identification of clinically significant cancers, ${ }^{3}$ as well as better disease staging. ${ }^{4}$ Active surveillance has taken the stage and has been implemented with different protocols worldwide for very low-risk, low-risk, and selected intermediate-risk disease. ${ }^{5,6} \mathrm{~A}$ better understanding of tumor biology and the availability of novel prognostic and diagnostic tools have significantly changed the paradigm in the management of this disease. Several genomic tests - such as Prolaris ${ }^{\circledR}$, Oncotype DX ${ }^{\circledR}$, and Decipher $^{\circledR}$ - are already commercially available, and are now being used, in addition to traditional clinical nomograms, although their role is yet to be defined. ${ }^{7}$ Recent introduction of 3D printing technology might further facilitate surgical planning (Fig. 1).

After the golden era of laparoscopic prostate surgery, modern prostate cancer surgery has been mainly driven by the rapid adoption of robot-assisted laparoscopy radical prostatectomy (RARP), ${ }^{8,9}$ which now represents the gold standard treatment option in most industrialized countries. $^{10,11}$ Moreover, the implementation of multi- parametric MRI imaging to prostate biopsy techniques ${ }^{12}$ (Fig. 2) has paved the way to the concept of "focal therapy". ${ }^{13}$ This paragraph will be focused on these two main areas of clinical interest.

\section{Robotic surgery for prostate cancer}

\section{Refinements in RALP technique}

One of main advantages of robotic surgery is certainly represented by the magnification of the surgical field, allowing a better visualization and easier appreciation of fine anatomical details. Overall, a better understanding of surgical anatomy of the prostate has translated into recognition of key anatomical structures, and its possible variations. Thus, the RARP procedure can be regarded as an individualized operation that can be tailored to the specific characteristics of the patient and the cancer. ${ }^{14}$ The "trifecta" (cancer control, continence, and potency) has become the standard metrics to assess the outcomes of RARP,${ }^{15}$ as patient reported health related quality of life is regarded as an important parameter to consider in prostate cancer treatment. ${ }^{16}$ Therefore, refinements in surgical technique have been mainly directed towards the preservation of patient's functions, namely urinary continence and sexuality.

Factors contributing to the continence status of men undergoing prostate cancer surgery have been extensively investigated. Besides preoperative parameters (such as age, prostate size, membranous urethral length, and BMI), the impact of surgical dissection, damage to neurovascular bundles, and postoperative fibrosis have been recognized

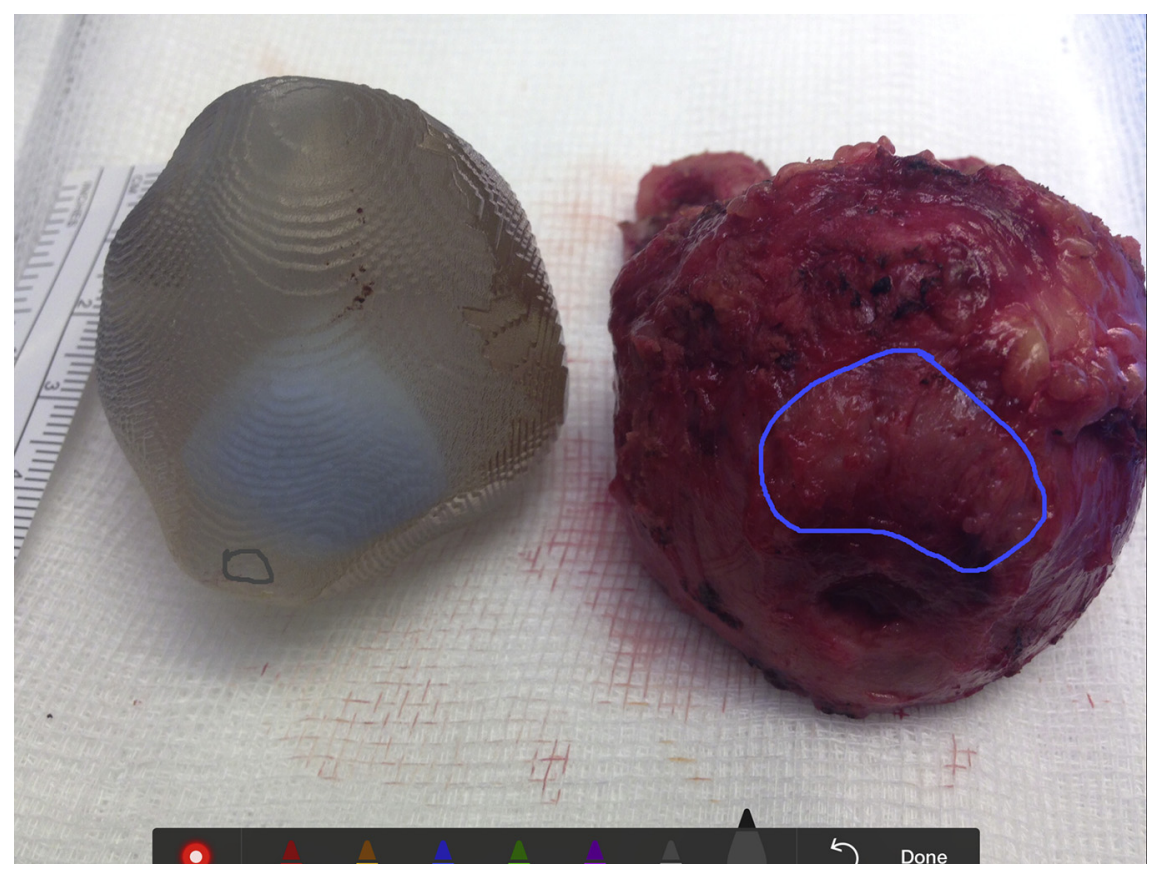

Figure 1. 3D printed prostate showing anterior T3 tumor close to sphincter (courtesy of Prof. Prokar Dasgupta, King's College London, Guy's Hospital, London, UK). 


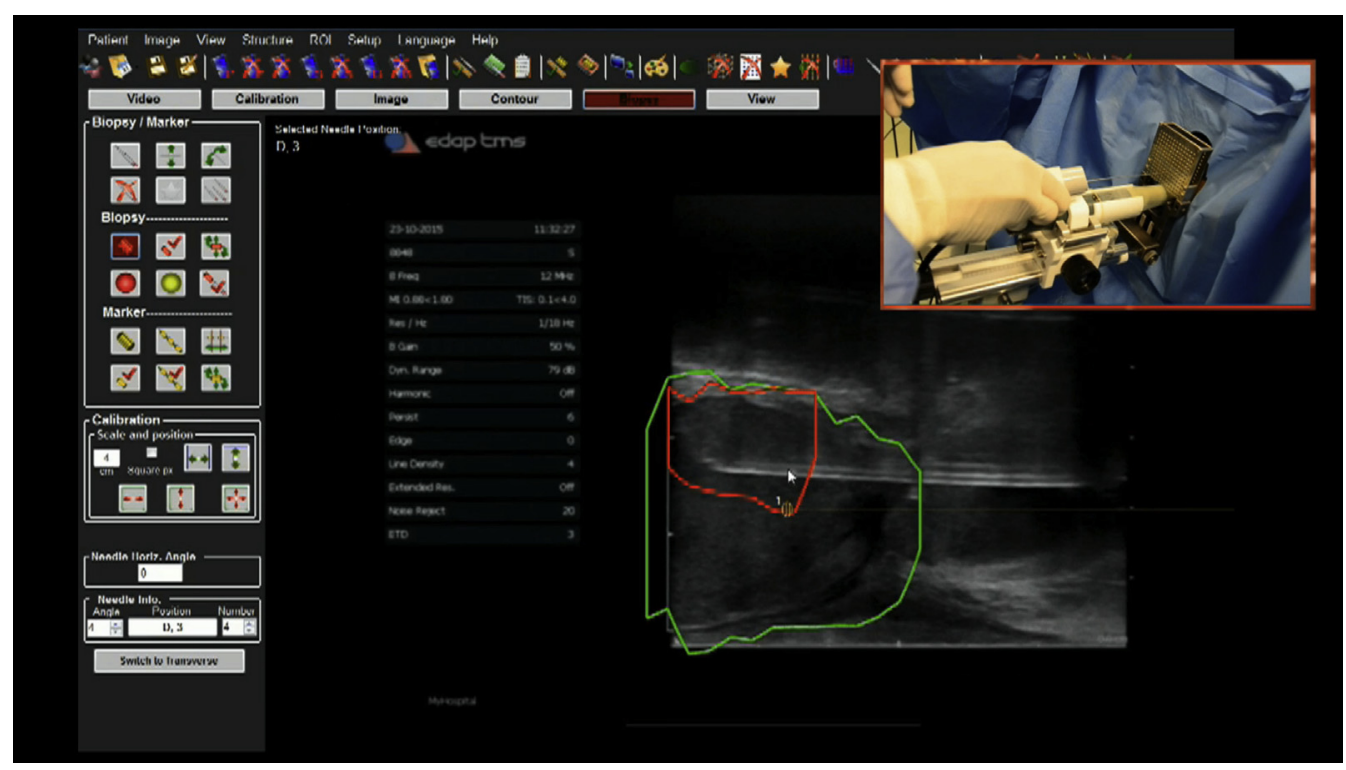

Figure 2. MRI-US fusion transperineal prostate biopsy (courtesy of Prof. Francesco Porpiglia, San Luigi Hospital, University of Turin, Orbassano, Italy).

(Fig. 3). ${ }^{17}$ Several techniques aiming at restoring the disrupted anatomy secondary to the removal of the prostate gland have been investigated (Table 1). ${ }^{18-30}$ These techniques are based on three key concepts: preservation (bladder neck sparing, puboprostatic ligaments, puboprostatic collar, pubovesical complex, urethral length); reconstruction (posterior and/or anterior reconstruction) (Fig. 4); reinforcement (bladder neck plication and/or sling suspension). ${ }^{31}$ This has also resulted in a debate on the use of a standard nomenclature - such as the one proposed by the ESUT - to facilitate outcome comparisons and surgical education. ${ }^{32}$

Sexual dysfunction can represent a common clinical issue in patients undergoing prostate cancer surgery. ${ }^{33}$ Several factors contribute to postoperative recovery of erectile function, including patient characteristics (age, baseline erectile function, co-morbidities), surgical technique (non-versus uni- or

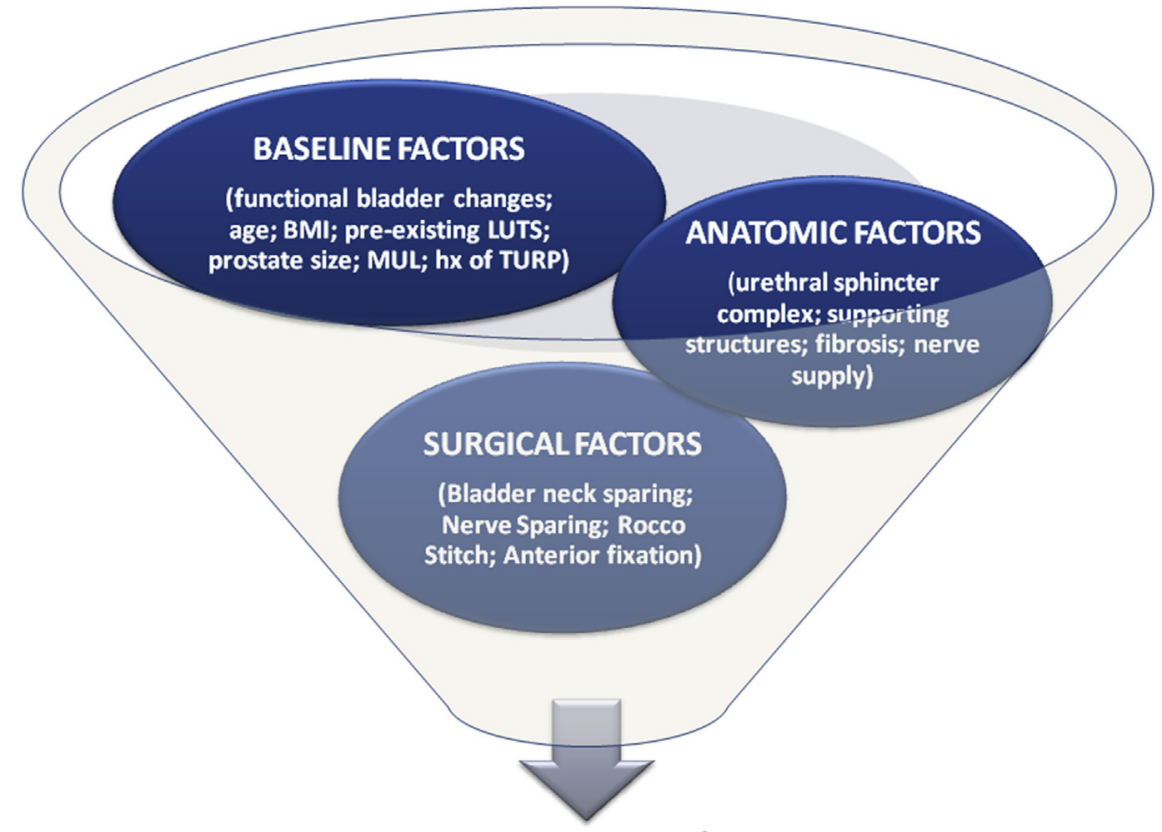

Post prostatectomy continence status

Figure 3. Factors contributing to urinary continence status post radical prostatectomy. ${ }^{17}$ 
Table 1

Overview of surgical techniques aiming at improved continence status after RALP.

\begin{tabular}{|c|c|c|}
\hline $\begin{array}{l}\text { Anatomical } \\
\text { principle }\end{array}$ & Reference & Technique \\
\hline Preservation & $\begin{array}{l}\text { Friedlander } \\
\operatorname{Lim}^{30}\end{array}$ & $\begin{array}{l}\text { Bladder neck sparing } \\
\text { Retzius sparing }\end{array}$ \\
\hline \multirow[t]{5}{*}{ Reinforcement } & $\begin{array}{l}\text { Lee }^{24} \\
\text { Bahler }^{22}\end{array}$ & $\begin{array}{l}\text { Bladder neck plication stitch } \\
\text { Small intestinal submucosa bladder } \\
\text { neck sling }\end{array}$ \\
\hline & $\mathrm{Lei}^{19}$ & $\begin{array}{l}\text { Selective suture ligation of dorsal } \\
\text { venous complex }\end{array}$ \\
\hline & Patel $^{20}$ & Periurethral suspension stitch \\
\hline & Nguyen $^{21}$ & $\begin{array}{l}\text { Urethral sling fashioned from } \\
\text { autologous vas deferens }\end{array}$ \\
\hline & Dal Moro $^{27}$ & $\begin{array}{l}\text { Complete Reconstruction of the } \\
\text { Posterior Urethral Support (CORPUS) }\end{array}$ \\
\hline \multirow[t]{4}{*}{ Reconstruction } & $\begin{array}{l}\text { Propiglia }^{23} \\
\text { Student }^{25}\end{array}$ & $\begin{array}{l}\text { Total anatomical reconstruction } \\
\text { Advanced reconstruction of } \\
\text { vesicourethral support (ARVUS) }\end{array}$ \\
\hline & Jeong $^{26}$ & 1-step posterior reconstruction \\
\hline & Hurtes $^{28}$ & $\begin{array}{l}\text { Anterior retropubic suspension } \\
\text { with posterior reconstruction }\end{array}$ \\
\hline & Coelho $^{29}$ & Modified posterior reconstruction \\
\hline
\end{tabular}

bi-lateral nerve sparing; extrafascial versus inter- or intrafascial), and surgeon factors (surgical volume and skills) ${ }^{34}$ (Fig. 5). Despite extensive research in the field of prostate anatomy, controversies remain in regard to the location, distribution and function of periprostatic nerve fibers. Certainly, it is not possible to reproduce exactly the same dissection in every patient, and therefore the surgeon has to find for each case the best balance between an oncologic safe margin and the anatomical integrity of the nervous system (Fig. 6). As anatomical knowledge has increased, there has been a shift from the simplistic dichotomy "non-nerve sparing versus nerve sparing" or "intra-inter-extra-fascial" towards the concept of "incremental nerve sparing" or "incremental safety margin". ${ }^{14}$ In this regard, grading systems have been proposed to define the extent of tissue margin on the prostate. $^{10,35,36}$ Tewari et al. proposed four grades of dissection by using the veins on the lateral aspect of the prostate as a vascular landmark. ${ }^{35}$ Patel and coworkers proposed an inverse (grade 5 optimal nerve sparing, grade 1 no nerve sparing) fivegrade scale by using the arterial periprostatic vasculature as landmark and by identifying a "landmark" artery. ${ }^{36}$

The concept that cautery-free dissection or pinpointed low-energy cauterization should be implemented when aiming at nerve preservation is well established. ${ }^{33}$ In addition to this, investigators have explored several other technical refinements that would minimize nerve damage. Some noted that counter-traction on the neurovascular bundle (done by either the assistant or the console surgeon) might translate into neuropraxia and delayed recovery of sexual function. ${ }^{37}$ A Retzius-sparing approach pioneered by Bocciardi and coworkers in order to perform the entire procedure through the pouch of Douglas might translate into higher potency rates. ${ }^{38}$ The Martini Clinic group described a safe and effective way of performing intraoperative neurovascular structure-adjacent frozen section examination (so called "NeuroSAFE") during RARP. ${ }^{39}$ More recently, Patel et al. showed that the placement of dehydrated human amnion/chorion membrane around the neurovascular bundle can translate into earlier return of potency. ${ }^{40}$ Other technologies are being investigated to facilitate precise identification of periprostatic nervous structures, such as fluorescence imaging and confocal laser endomicroscopy. ${ }^{41}$

\section{RARP: long term oncological data and comparison with open surgery}

More than 15 years have passed since RARP was first described, ${ }^{42}$ and mature data are now available
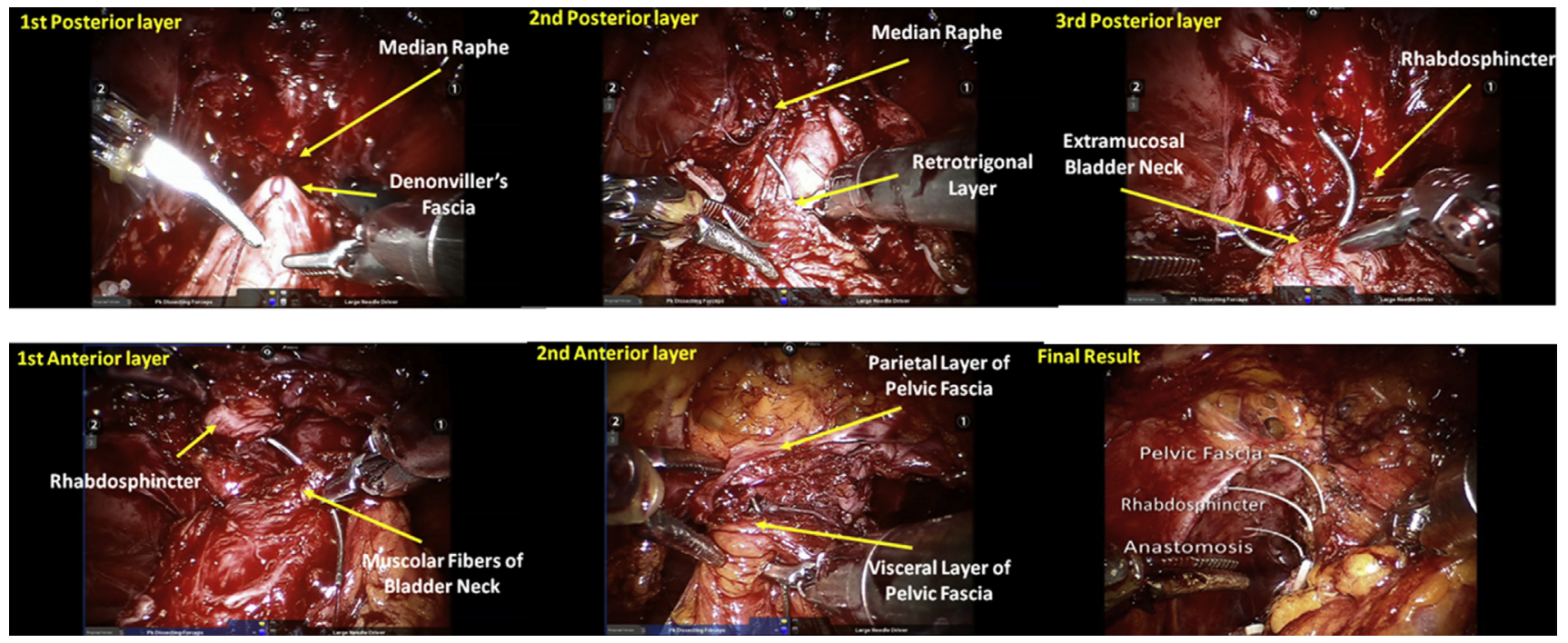

Figure 4. Total (posterior and anterior) anatomical reconstruction during robot-assisted radical prostatectomy (courtesy of Prof. Francesco Porpiglia, San Luigi Hospital, University of Turin, Orbassano, Italy). 


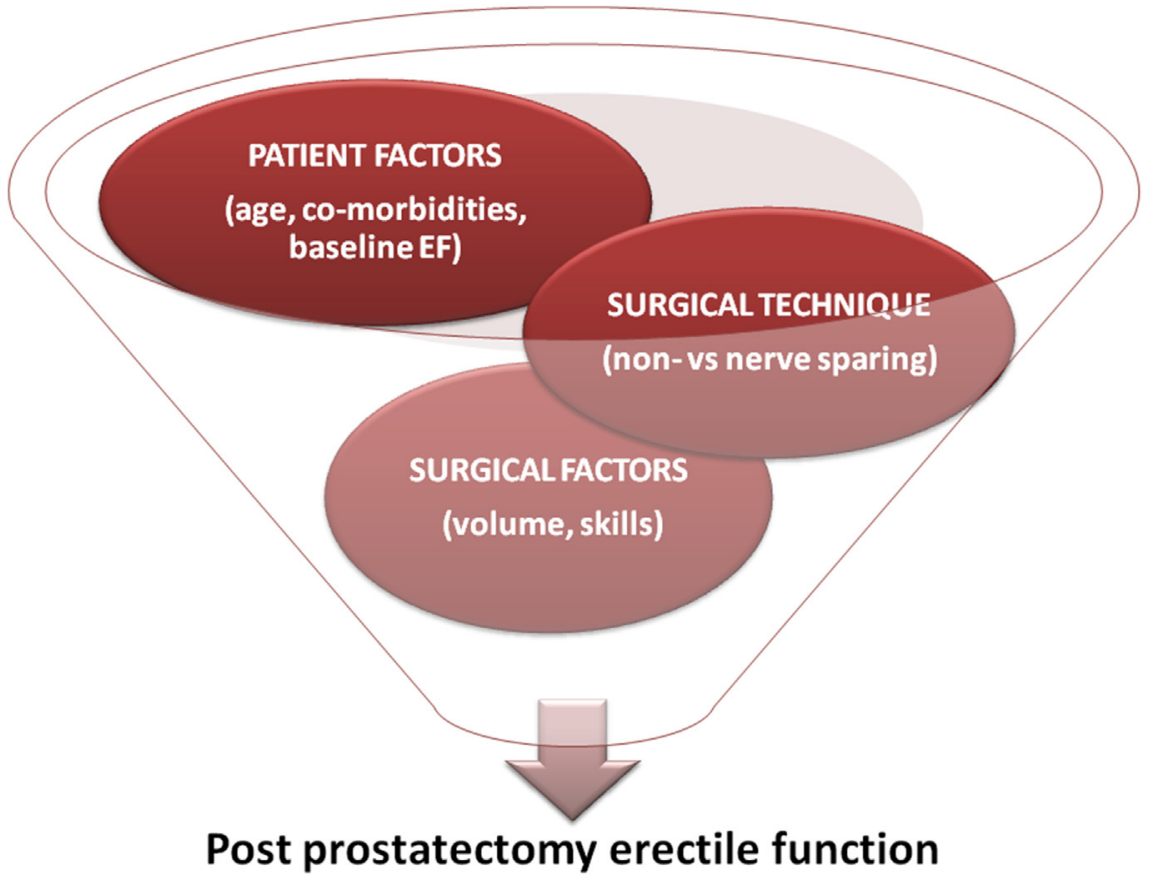

Figure 5. Factors contributing to potency status post radical prostatectomy. ${ }^{34}$

showing that the procedure is effective in long term cancer control, even in patients with high-risk disease (Table 2). ${ }^{43-49}$

Theoretically, robot-assisted surgery should be the ideal model to determine the impact and limitations of "surgical precision" providing better ergonomic for the surgeon, particularly during reconstructive steps, better vision and magnification during dissection of the prostate and surrounding anatomical details. Nevertheless, there is still a debate on "robotic versus open surgery" for prostate cancer mainly fueled by large population-based data analyses (Table 3). ${ }^{50-56} \mathrm{Hu}$ et al. reported two large analyses from the SEER Medicare dataset. They found that RARP is associated with lower likelihood of positive surgical margins for intermediate-risk (15.0\% versus $21.0 \%$; OR: 0.66$)$ and high-risk (15.1\% versus 20.6\%; OR: 0.70) disease, as well as less use of additional cancer therapy (at 24 months OR: 0.67). ${ }^{50}$ Moreover, they found that RARP is associated with an equivalent risk of all cause (HR 0.85) and cancer specific (HR 0.85) mortality. ${ }^{55}$

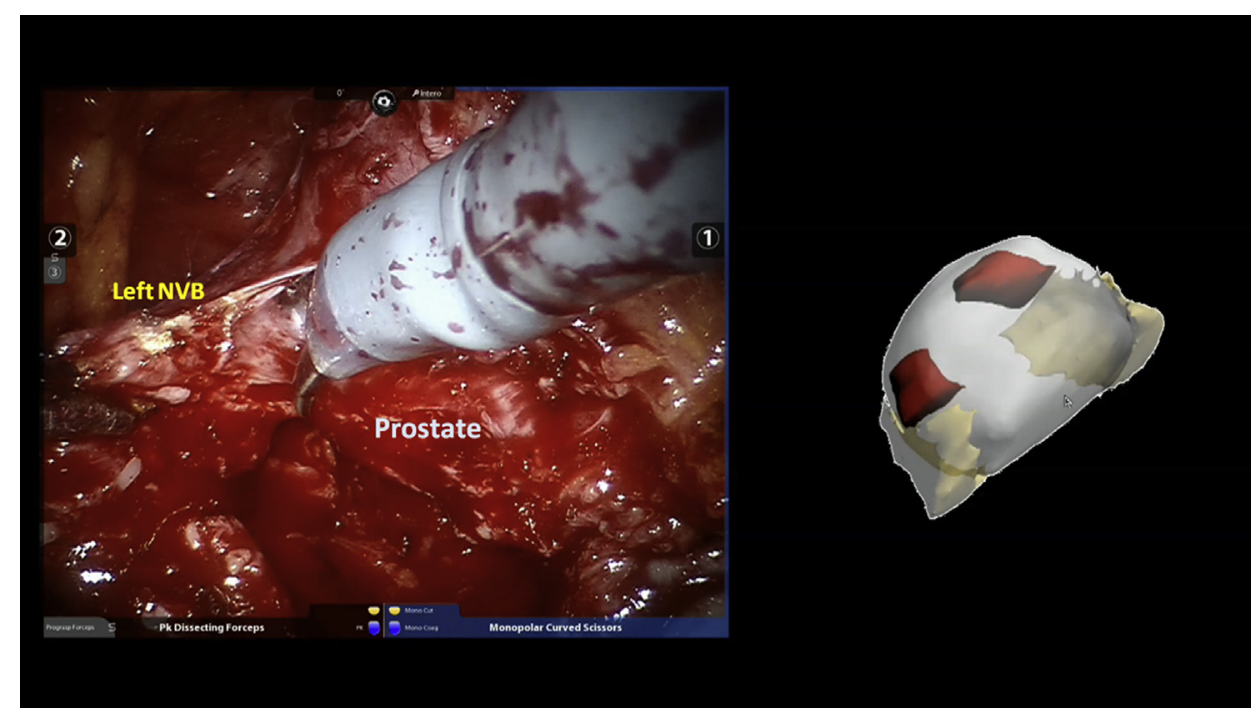

Figure 6. Image-guided nerve sparing robot assisted radical prostatectomy (courtesy of Prof. Francesco Porpiglia, San Luigi Hospital, University of Turin, Orbassano, Italy). 
Table 2

Oncological outcomes of RALP: overview long term data.

\begin{tabular}{|c|c|c|c|c|c|c|c|}
\hline Reference & Institution & Pts, $\mathrm{n}$ & Time period & $\begin{array}{l}\text { Median } \\
\text { follow-up, } \\
\text { months }\end{array}$ & BRFS & CRFS & CSS \\
\hline Sooriakumaran $^{43}$ & Karolinska University, Stockholm, Sweden & 944 & $2002-06$ & 75.6 & 82.6\%@9yrs & - & - \\
\hline Abdollah $^{44}$ & $\begin{array}{l}\text { Henry Ford Hospital, Detroit, MI, USA; } \\
\text { Martini Clinic, Hamburg, Germany; } \\
\text { San Raffaele University, Milan, Italy }\end{array}$ & $1100^{*}$ & $2002-13$ & 49 & $50 \% @ 10 y r s$ & 87\%@10yrs & - \\
\hline $\operatorname{Diaz}^{45}$ & Henry Ford Hospital, Detroit, MI, USA & 483 & $2001-03$ & 120 & $73.1 \% @ 10 y r s$ & - & $98.8 @ 10 y r s$ \\
\hline Abdel Raheem ${ }^{46}$ & Yonsei University, Seoul, Korea & 800 & $2005-10$ & 64 & $76.4 @ 5 \mathrm{yrs}$ & $94.6 \% @ 5 y r s$ & $96.7 \% @ 5 y r s$ \\
\hline Suardi $^{47}$ & $\begin{array}{l}\text { OLV Robotic Surgery Institute, } \\
\text { Aalst, Belgium }\end{array}$ & 184 & - & 67.5 & $81 \% @ 7 \mathrm{yrs}$ & - & - \\
\hline Billia $^{48}$ & $\begin{array}{l}\text { Guy's and St. Thomas' Hospitals, } \\
\text { London, UK }\end{array}$ & 175 & - & - & $95.4 \% @ 5$ yrs & - & $98.3 \% @ 5 y r s$ \\
\hline Liss $^{49}$ & $\begin{array}{l}\text { University of California-Irvine, } \\
\text { Orange, CA, USA }\end{array}$ & 289 & $2002-06$ & - & $84.9 \% @ 5 y r s$ & - & $99 \% @ 5 y r s$ \\
\hline
\end{tabular}

BRFS = Biochemical recurrence free survival; CRFS = Clinical recurrence free survival; MFS *D'Amico high risk only.

In another large retrospective analysis of administrative data Leow et al. looked at outcomes and costs of over 600,000 radical prostatectomies done in the USA over a 10 -year period. ${ }^{52}$ First of all, they found utilization of robotic surgery rapidly increased from $1.8 \%$ in 2003 to $85 \%$ in $2013(\mathrm{p}<0.001)$. Moreover, RARP patients were less likely to experience complications ([OR 0.68, $\mathrm{p}<0.001$ ) or to receive blood products (OR 0.33, $\mathrm{p}=0.002$ ). While 90-day direct hospital costs were higher for RARP, costs were no longer significantly different between open and robotics for the highest-volume surgeons $(\geq 104$ cases/yr; $+\$ 1990, p=0.40)$ and hospitals $(\geq 318$ cases $/ y r ;+\$ 1225, \mathrm{p}=0.39)$. Haglind et al. reported a large prospective controlled nonrandomized trial involving 14

Table 3

Robotic versus open radical prostatectomy: high quality comparative studies to date.

\begin{tabular}{|c|c|c|c|c|c|c|}
\hline Reference & Study design & Country & No. of patients & Study period & Endpoints & Main findings \\
\hline$\overline{\mathrm{Hu}^{50}}$ & $\begin{array}{l}\text { Retrospective observational } \\
\text { study from SEER database }\end{array}$ & USA & $\begin{array}{l}5556 \text { RALP } \\
\text { versus } 7878 \text { ORP }\end{array}$ & 2004-09 & $\begin{array}{l}\text { SM status; use } \\
\text { of additional } \\
\text { cancer therapy }\end{array}$ & $\begin{array}{l}\text { RALP associated with } \\
\text { improved SM status for } \\
\text { intermediate- and high-risk } \\
\text { disease and less use of post- } \\
\text { prostatectomy ADT and RT }\end{array}$ \\
\hline Haglind $^{51}$ & $\begin{array}{l}\text { Prospective, controlled, non } \\
\text { randomized multicenter } \\
\text { (LAPPRO study) }\end{array}$ & Sweden & $\begin{array}{l}1847 \text { RALP } \\
\text { versus } 778 \text { ORP }\end{array}$ & $2008-11$ & $\begin{array}{l}\text { UI and EF @ } \\
12 \text { months; SM status }\end{array}$ & $\begin{array}{l}\text { RALP modestly beneficial in } \\
\text { preserving EF. } \\
\text { No significant difference } \\
\text { regarding UI or SM }\end{array}$ \\
\hline Leow $^{52}$ & $\begin{array}{l}\text { Retrospective observational } \\
\text { study from Premier Hospital } \\
\text { database }\end{array}$ & USA & $\begin{array}{l}311,135 \text { RALP } \\
\text { versus } 318,458 \text { ORP }\end{array}$ & $2003-13$ & Outcomes and costs & $\begin{array}{l}\text { RALP confers a perioperative } \\
\text { morbidity advantage; costs no } \\
\text { longer significantly different } \\
\text { when highest-volume } \\
\text { surgeons and hospitals }\end{array}$ \\
\hline $\mathrm{Seo}^{53}$ & $\begin{array}{l}\text { Systematic review and } \\
\text { meta-analysis }\end{array}$ & Korea & 61 studies & - & Outcomes & $\begin{array}{l}\text { RALP better risk of UI, EF, } \\
\text { and complications. SM and } \\
\text { BCR rates comparable }\end{array}$ \\
\hline Yaxley $^{54}$ & RCT & Australia & $\begin{array}{l}157 \text { RALP } \\
\text { versus } 151 \text { ORP }\end{array}$ & $2010-14$ & $\begin{array}{l}\text { UI and EF @ } 6 \\
\text { and } 12 \text { weeks }\end{array}$ & Similar UI and EF outcomes \\
\hline $\mathrm{Hu}^{55}$ & $\begin{array}{l}\text { Retrospective observational } \\
\text { study from SEER database }\end{array}$ & USA & $\begin{array}{l}6430 \text { RALP } \\
\text { versus } 9161 \text { ORP }\end{array}$ & $2003-12$ & $\begin{array}{l}\text { ACM, PCSM and } \\
\text { use of additional } \\
\text { cancer therapy }\end{array}$ & $\begin{array}{l}\text { RALP with less use of } \\
\text { additional postoperative } \\
\text { cancer therapies, and } \\
\text { equivalent ACM and PCSM }\end{array}$ \\
\hline Thompson $^{56}$ & $\begin{array}{l}\text { Prospective observational } \\
\text { single surgeon study }\end{array}$ & Australia & $\begin{array}{l}866 \text { RALP } \\
\text { versus } 686 \text { ORP }\end{array}$ & $2006-12$ & $\begin{array}{l}\text { Quality of life } \\
\text { and SM }\end{array}$ & $\begin{array}{l}\text { After a long learning curve, } \\
\text { RALP has superior sexual, } \\
\text { early urinary, and pT2 SM } \\
\text { outcomes }\end{array}$ \\
\hline
\end{tabular}

SEER = surveillance epidemiology and end results; LAPPRO = laparoscopic prostatectomy robot open; $\mathrm{RCT}=$ randomized controlled trial; $\mathrm{RALP}=$ robotassisted laparoscopic radical prostatectomy; $\mathrm{ORP}=$ open radical prostatectomy; $\mathrm{SM}=$ surgical margin; $\mathrm{UI}=$ urinary incontinence; $\mathrm{EF}=$ erectile function; $\mathrm{ADT}=$ androgen deprivation therapy; $\mathrm{RT}=$ radiation therapy; $\mathrm{BCR}=$ biochemical recurrence; $\mathrm{ACM}=$ all cause mortality; $\mathrm{PCSM}=$ prostate cancer specific mortality. 
Table 4

Ongoing trials on radical surgical treatment of primary tumor in patients with oligometastatic prostate cancer (www.clinicaltrials.gov).

\begin{tabular}{|c|c|c|c|c|c|c|}
\hline Institution & Name of trial & Study design & Treatment groups & Study sample & Primary endpoint & $\begin{array}{l}\text { Expected } \\
\text { to be reported }\end{array}$ \\
\hline $\begin{array}{l}\text { MD Anderson Cancer Center } \\
\text { (USA) }\end{array}$ & - & RCT & BST versus $\mathrm{BST}+\mathrm{RP}$ or RT & 120 & PFS & 2018 \\
\hline Oxford University (UK) & TRoMbone & RCT & $\mathrm{ADT}$ versus $\mathrm{ADT}+\mathrm{RP}$ & 50 & $\begin{array}{l}\text { Feasibility to } \\
\text { randomize } \\
\text { @ } 6 \text { months }\end{array}$ & 2018 \\
\hline Martini Clinic (Germany) & g-RAMPP & RCT & $\mathrm{ADT}$ versus $\mathrm{ADT}+\mathrm{RP}$ & 452 & CSS & 2025 \\
\hline University of Vienna (Austria) & - & $\begin{array}{l}\text { Prospective } \\
\text { phase I-II }\end{array}$ & $\mathrm{RP}$ & 50 & $\begin{array}{l}\text { 90-day } \\
\text { complication rate }\end{array}$ & 2021 \\
\hline
\end{tabular}

$\mathrm{RCT}=$ randomized clinical trial; PFS = progression-free survival; CSS = cancer specific survival; BST = best systemic therapy; RP = radical prostatectomy; $\mathrm{RT}=$ radiation therapy; ADT = androgen deprivation therapy.

Centers from Sweden and comparing robotic $(\mathrm{n}=1847)$ to open $(n=778)$ radical prostatectomy. ${ }^{51}$ They could only find a modest benefit of robotic surgery for preservation of erectile function, whereas no difference was found in terms of continence and positive margin rates. Seo et al. reported the latest systematic review and meta-analysis of studies comparing open to robotic surgery for prostate cancer. ${ }^{53}$ They included 61 studies, and confirmed that RARP carries a lower risk of complications and urinary incontinence, as well as higher potency rate, whereas positive margin rates and recurrence free survival were similar. However, the authors pointed out the low quality of available studies.

Moreover, they did not include the only available randomized controlled trial, which was recently reported by Yaxley et al. from the Royal Brisbane and Women's Hospital (Brisbane, Australia) ${ }^{54}$ Primary outcomes were urinary function and sexual function at 6 weeks, 12 weeks, and 24 months and oncological outcome (positive surgical margin status and biochemical and imaging evidence of progression at 24 months). The trial was powered to assess health-related and domain-specific quality of life outcomes over 24 months. In this preliminary report the authors reported the early outcomes at 6 weeks and 12 weeks. Overall, 151 in the radical retropubic prostatectomy group proceeded to surgery and 157 in the RARP group. Urinary function scores did not differ significantly between the radical retropubic prostatectomy group and RARP group at 6 weeks post-surgery $(\mathrm{p}=0.09)$ or 12 weeks postsurgery $(p=0.48)$. Sexual function scores also did not differ significantly between the groups at 6 weeks $(\mathrm{p}=0.45)$ or 12 weeks $(\mathrm{p}=0.18)$ post-surgery. There was also no difference for proportion of positive surgical margins between the two groups (10\% for open and $15 \%$ for robotic, $\mathrm{p}=0.21$ ), as well as for postoperative complications (9\% for open and $4 \%$ for robotic, $\mathrm{p}=0.052$ ). Obviously, these findings generated different interpretations. As there was no difference between the two technique one might argue that the application of robotic surgery does not provide any benefit to the patient. On the other hand, by taking a close look, few important points need to be pointed out. The two surgeons involved in the trial had a very different surgical experience as one had performed about 200 robotic cases (in 2 years) and the other over 1500 open cases (in 15 years) at the start of the trial. Thus, it can be argued that robotic surgery allowed the less experienced surgeon to achieve equal outcomes significantly faster. This concept is also supported by the findings from the study by Thompson et al., who analyzed over 1550 cases to determine whether a well established open surgeon (over 3000 cases) could achieve better outcomes by switching to robotics. They found that, after a learning curve, the surgeon could indeed improve, especially their functional outcomes. ${ }^{56}$

New frontiers of prostate cancer surgery: oligometastatic cancer and nodal recurrent cancer

Over the past years, oligometastatic cancer - clinically defined as disease with up to five extra-pelvic lesion - as has been recognized as separate clinical entity from advanced cancer, mostly thanks to the implementation of functional imaging. ${ }^{57}$ A growing body of evidence seems to support the hypothesis that a radical treatment to their primary tumor, alongside "metastasis-directed therapy", might be beneficial for patients with oligometastatic cancer. These have been suggested by recent large population-based studies, from both USA $^{58}$ and Europe. ${ }^{59}$ Gandaglia et al. reported on the outcomes of a selected cohort of 11 patients with oligometastatic disease treated with radical prostatectomy and extended pelvic lymph node dissection. Adjuvant androgen deprivation therapy was administered to 10 patients (91\%). The 7-yr clinical progression-free and cancer specific survival rates were $45 \%$ and $82 \%$, respectively. ${ }^{60}$ Ongoing trials whose findings will be available within the next few years, will better define the best approach for oligometastatic prostate cancer (Table 4) (www.clinicaltrials.gov).

Salvage lymph node dissection has been recently proposed as possible treatment option in selected prostate cancer patients with disease recurrence limited to regional and/or retroperitoneal nodes. ${ }^{61}$ This novel therapeutic approach has become available due to recent advances in the field of nuclear medicine imaging modalities, such as PET/CT and PET/MRI. ${ }^{62}$ Several centers have reported initial series with encouraging results (Table 5), ${ }^{63-67}$ but further clinical investigation is required. 
Table 5

Reported series on salvage lymph node dissection in recurrent prostate cancer.

\begin{tabular}{|c|c|c|c|c|c|}
\hline Reference & $\begin{array}{l}\text { No. of } \\
\text { patients }\end{array}$ & Imaging modality & $\begin{array}{l}\text { Surgical } \\
\text { technique }\end{array}$ & Follow-up & Outcomes \\
\hline Suardi ${ }^{63}$ & 59 & 11C-choline PET/CT scan & Open & $81.8 \mathrm{mo}$ & $\begin{array}{l}\text { BR: } 59.3 \% \\
\text { 8-yr BCR-free survival in patients with BR: } 23 \% \\
\text { 8-yr CR- and CSM-free survival: } 38 \% \text { and } 81 \%\end{array}$ \\
\hline Osmonov $^{64}$ & 45 & 11C-choline PET/CT & & $42.7 \mathrm{mo}^{*}$ & BCR-free survival: $73.3 \%$; CSS: $91.7 \%$; OS: $80.6 \%$ \\
\hline Winter $^{65}$ & 13 & 11C-choline PET/CT & & $72 \mathrm{mo}$ & BR: $91 \%$; Complete biochemical remission: $30 \%$ \\
\hline Montorsi $^{66}$ & 16 & 11C-choline or (68)Ga-PSMA PET/CT & Robotic & 40 days & BR: $33.3 \%$ \\
\hline de-Castro Abreu ${ }^{67}$ & 10 & Carbon-11 acetate PET/CT imaging & & $2 \mathrm{mo}$ & $\begin{array}{l}\text { In patients with positive nodes, median PSA } \\
\text { decreased by } 83 \%\end{array}$ \\
\hline
\end{tabular}

$\mathrm{BR}=$ biochemical response; $\mathrm{BCR}=$ biochemical recurrence; $\mathrm{CR}=$ clinical recurrence; $\mathrm{CSM}=$ cancer specific mortality; $\mathrm{CSS}=$ cancer specific survival; OS = overall survival; ${ }^{\wedge}=$ median; $*=$ mean.

\section{Focal therapy for prostate cancer}

Focal therapy has been conceived as a minimally invasive tissue-preserving treatment strategy for localized prostate cancer. ${ }^{68}$ The rationale supporting this strategy is mainly based on the concept of "index lesion", and on the increased ability to detect this lesion (and to rule out high-risk lesions) thanks to the standardization of MRI imaging-based biopsy techniques. ${ }^{69}$

In a recent systematic review, Valerio et al. analyzed 37 studies including over 3200 patients in order to summarize the current evidence on different modalities of focal therapy for prostate cancer. ${ }^{70}$ Overall, seven different sources of energy have been tested, with some of them (high-intensity focused ultrasound [HIFU], cryotherapy, photodynamic therapy [PDT], brachytherapy) studied on larger samples, some others (laser interstitial thermotherapy [LITT], irreversible electroporation [IRE]) still in a more preliminary stage of assessment (Table 6). Among these, HIFU and cryotherapy are those that have been mostly implemented in clinical practice. However, evidence supporting the use of newer technologies, such as PDT, in low-risk cancer is being reported in large scale phase III studies. ${ }^{71}$

\section{Bladder cancer}

Urothelial bladder cancer represents a complex disease with a high prevalence, and high morbidity and mortality if not optimally treated. ${ }^{72}$ Traditionally, its best surgical treatment depends on the stage of the disease: for non-muscle-invasive cancer, transurethral resection (TURB) followed by induction and maintenance immunotherapy with intravesical BCG or chemotherapy represents the current standard ${ }^{73}$; for muscle-invasive cancer, radical cystectomy with neoadjuvant chemotherapy offers the best chance for cure, whereas in selected patients bladder-sparing modalities, consisting of transurethral resection with chemo-radiation, can be considered. ${ }^{74}$

Over the past decade, two major areas of research in the field of bladder surgery have been investigated, that of new optimal imaging technologies for non-muscle-invasive disease, and that of robotic surgery for the management of muscle-invasive disease.

\section{Innovations in optical imaging technology}

Precision surgery for bladder cancer patients mostly relies on initial diagnostic endoscopic accuracy. The current standard "white light cystoscopy" presents significant shortcomings, including suboptimal detection of flat lesion (carcinoma in situ), inaccurate tumor delineation to facilitate complete resection, challenging differential diagnosis with inflammatory lesions, and difficult determination of grade and stage. Therefore, novel technologies have been developed and implemented to aid the surgeon during endoscopic management of bladder cancer. ${ }^{75}$ These can be broadly categorized in macroscopic (photodynamic diagnosis [PDD]; narrow band imaging [NBI]; post-processing

Table 6

Focal therapy for prostate cancer: current evidence. ${ }^{70}$

\begin{tabular}{lllllllll}
\hline Technique & $\begin{array}{l}\text { No. of } \\
\text { studies }\end{array}$ & $\begin{array}{l}\text { No. of } \\
\text { patients }\end{array}$ & $\begin{array}{l}\text { Median follow-up, } \\
\text { months }\end{array}$ & $\begin{array}{l}\text { Overall } \\
\text { survival, } \%\end{array}$ & $\begin{array}{l}\text { Disease specific } \\
\text { survival, \% }\end{array}$ & $\begin{array}{l}\text { Adverse event } \\
\text { rate, } \%\end{array}$ & $\begin{array}{l}\text { Continence } \\
\text { rate, } \%\end{array}$ & $\begin{array}{l}\text { Potency } \\
\text { rate, } \%\end{array}$ \\
\hline HIFU & 13 & 346 & 12 & 100 & 100 & 1.5 & 8.5 \\
Cryotherapy & 11 & 1950 & 26 & 100 & 100 & 2.5 & 100 \\
PDT & 3 & 116 & 6 & 100 & 100 & 10.6 & 100 \\
LITT & 4 & 50 & 4.5 & 100 & 100 & 0 & na \\
Brachytherapy & 2 & 339 & 61 & na & 99.9 & na & 100 \\
IRE & 3 & 66 & 6 & 100 & 100 & 0 & 95.2 \\
\hline
\end{tabular}

HIFU = high-intensity focused ultrasound; PDT = photodynamic therapy; LITT = laser interstitial thermotherapy; IRE = Irreversible electroporation; na $=$ not available. 
of the endoscopic image [SPIES]) and microscopic (confocal laser endomicroscopy [CLE]; optical coherence tomography $[\mathrm{OCT}])$ ones.

PDD is also known as "fluorescence" or "blue light" cystoscopy. It requires preoperative intravesical administration of a contrast agent (a protoporphyrin analogue), a blue light $(380-480 \mathrm{~nm})$ source, and specialized lens and camera. PDD has been implemented in Europe for the past two decades using 5-aminolevulinic acid (5-ALA). Its derivative hexaminolevulinate (HAL; Hexvix ${ }^{\circledR} /$ Cysview $^{\circledR}$ ) has become more recently available and it was approved by the FDA in 2010 on the basis of a phase III trial showing a $16 \%$ reduction in rate of recurrence at 9 months versus white light cystoscopy. ${ }^{76}$ PDD seems to provide a better detection of both papillary and flat appearing CIS lesions. Burger et al. reported a meta-analysis of raw data from prospective studies on 1345 patients, and they found that PDD detected significantly more Ta tumors $(14.7 \%)$ and CIS lesions (40.8\%) than standard cystoscopy. Moreover, about $25 \%$ patients with at least one additional $\mathrm{Ta} / \mathrm{T} 1$ tumor was identified when using PDD, and in $26.7 \%$ of patients, CIS was detected only by PDD. Overall, recurrence rates up to 12 months were significantly lower with PDD (34.5\% versus $45.4 \%) .{ }^{77}$ However, a prospective randomized multicenter study found no significant difference in tumor recurrence and progression when using PDD. ${ }^{78}$ In another pooled analysis of 3 phase III multicenter trials detection rate for CIS was $87 \%$ with PDD and $75 \%$ for standard cystoscopy. ${ }^{79}$ However, no data to date have suggested that use of PDD translates into a reduction in disease progression. False positive can be regarded as a drawback of the technology, as they occur in $10-12 \%$ of patients. $^{76}$

NBI is a technology that filters out the red spectrum of white light resulting in blue and green spectra that are preferentially absorbed by hemoglobin, thus enhancing the mucosal and sub-mucosal vasculature without need of any dye. This technology has been incorporated into rigid and flexible scopes, which carry a toggling functionality between white light and NBI, allowing real time assessment of suspicious areas. The first study on NBI was reported by Herr and Donat in 2008, suggesting a better detection rate than white light cystoscopy. ${ }^{80}$ Since then, multiple other series have been reported. A recent meta-analysis of 8 studies including 1022 patients showed the sensitivity and specificity of NBI and white light cystoscopy to be $94 \%$ versus $85 \%$ and $85 \%$ versus $87 \%$, respectively. ${ }^{81}$ Another recent meta-analysis demonstrated that NBI-TURB can reduce the risk of recurrence at 3 months, 1 year and 2 years. ${ }^{82}$ The Clinical Research Office of the Endourological Society (CROES) conducted a prospective randomized single-blind multicentre study comparing NBI and white light in patients with primary non-muscle-invasive bladder cancer. Overall, 965 patients were enrolled in the study (481 underwent -assisted TURB and 484 received NBI-assisted TURB). In patients at low risk for disease recurrence, recurrence rates at 12 months were significantly lower in the NBI group (5.6\% versus $27.3 \% ; \mathrm{p}=0.002) .{ }^{83}$ Similar results can be obtained by the use of SPIES, as the image quality and definition is similar to NBI. ${ }^{41}$

While PDD, NBI and SPIES have been clinically implemented on a large scale, other technologies such as CLE and OCT are still considered investigational. CLE is a technology that allows real time microscopy of the mucosa, and, after being primarily used in gastroenterology, it has been recently approved for clinical use in the urinary tract as micro-endoscopy probes (up to $2.6 \mathrm{~mm}$ in diameter) passing through the channel of a standard rigid cystoscope are now available. ${ }^{84}$ Fluorescein is used as contrast agent to be administered intravesically or intravenously. Pioneer work by Sonn et al. showed that CLE is feasible and it can differentiate normal urothelium from bladder cancer. ${ }^{85}$ Clinical data remain limited and further investigation is awaited. OCT is another real time high-resolution imaging technology that provides cross sectional images of biologic tissues by relying on information gathered by reflected energy (similarly to B mode ultrasound). Current technology uses a $2.7 \mathrm{~mm}$ diameter probe that can be passed through the cystoscope allowing visualization of the different layers of the bladder wall and to distinguish benign from malignant characteristics. Few studies have assessed the classification of OCT-assisted cystoscopy of bladder lesions as benign or malignant with a sensitivity of $84-100 \%$ and a specificity of $65-89 \% .{ }^{86}$ Moreover, another study found a $90 \%$ positive predictive value for tumor invasion into the lamina propria. ${ }^{87}$ Also for OCT, clinical studies are going and further results awaited.

\section{Sexual and organ preserving approaches for radical cystectomy $(R C)$}

Open RC with pelvic lymph node dissection still represents the gold standard treatment for non-metastatic muscle-invasive and selected high-risk non-muscle-invasive bladder cancer. ${ }^{88}$ With better understanding of neurofunctional anatomy, sexual-preserving $\mathrm{RC}$ techniques have been developed over the years in order to achieve superior functional outcomes, in both male and female patients with bladder cancer $^{89}$ (Table 7). Long term data on "prostate sparing" $\mathrm{RC}$ have shown that this can be an oncologically safe procedure with excellent functional results in a subset of carefully selected patients. "Seminal vesicle" cystoprostatectomy also resulted in a high probability of preserving potency, without putting patients at unnecessary risk. " "Nerve sparing" radical cystoprostatectomy also showed to not compromise cancer control while providing improved postoperative quality of life. ${ }^{92,93}$ In female patients, genital sparing cystectomy (with preservation of the uterus, vagina and ovaries) is feasible in selected women, and it can provide good functional outcome, better sexual function, and favorable oncological outcome. ${ }^{94}$ A "nerve sparing" technique in female patients has also been obtained by avoiding damage to 
Table 7

Sexual sparing techniques for radical cystectomy: summary of functional and oncological outcomes..$^{90-95}$

\begin{tabular}{|c|c|c|c|c|c|c|c|c|}
\hline Gender & Techniques & $\begin{array}{l}\text { No. of } \\
\text { studies }\end{array}$ & $\begin{array}{l}\text { No. of } \\
\text { cases }\end{array}$ & $\begin{array}{l}\text { Potency } \\
\text { rate, } \%\end{array}$ & $\begin{array}{l}\text { Sexual activity } \\
\text { rate, } \%\end{array}$ & $\begin{array}{l}\text { Daytime continence } \\
\text { rate, } \%\end{array}$ & $\begin{array}{l}\text { Nighttime continence } \\
\text { rate, } \%\end{array}$ & $\begin{array}{l}\text { Local recurrence } \\
\text { rate, } \%\end{array}$ \\
\hline Male & $\begin{array}{l}\text { Prostate sparing } \\
\text { Seminal sparing } \\
\text { Nerve sparing }\end{array}$ & 12 & 1098 & $\begin{array}{l}80-90 \\
79 \\
29-78\end{array}$ & $\mathrm{Na}$ & $88-100$ & $31-98$ & $\begin{array}{l}10 \\
3 \\
6\end{array}$ \\
\hline Female & $\begin{array}{l}\text { Genital organ preserving } \\
\text { Nerve sparing }\end{array}$ & 14 & 318 & na & 86.7 & 70.3 & 67.2 & $0-13$ \\
\hline
\end{tabular}

the proximal urethra and to preserve the autonomic innervation of the rhabdosphincter. ${ }^{95}$

\section{Robotic surgery for bladder cancer}

Since the first description by Menon et al., in 2003, ${ }^{96}$ robot-assisted radical cystectomy (RARC) has been adopted in several institutions worldwide. ${ }^{97}$ Over the last decade, the debate has been mainly focused on the perioperative outcomes of RARC versus the open gold standard technique. A recent meta-analysis of 19 studies, including a total of 1779 patients (787 patients in the RARC group and 992 patients in the open group) suggested that, despite the longer operative time, patients undergoing RARC might benefit from lower complication rates, more lymph node yields, less estimated blood loss, lower need for transfusions, and shorter postoperative length of stay. ${ }^{98}$ However, another meta-analysis including only the four available RCTs comparing open to RARC, with a total of 239 patients, all with extracorporeal urinary diversion, found no significant difference between techniques in terms of perioperative morbidity, length of stay, positive surgical margin, lymph node yield. RARC group had significantly lower estimated blood loss and wound complications, but again required significantly longer operating time. ${ }^{99}$ Thus, further studies are needed to determine the benefit of the minimally invasive approach for radical cystectomy, and results from ongoing trials are largely awaited. ${ }^{100}$ These trials have to focus on the difficulty of urinary diversion by the robot-assisted intracorporeal approach as well as on the oncologic impact of the laparoscopic technique.

In this setting, one of the key-factor is certainly represented by the urinary diversion, as this is largely recognized as the surgical step most likely to be associated with occurrence of perioperative morbidity. During the early phase of RARC, extracorporeal urinary diversions were mostly preferred. Over the past 5 years, the evolution of robotic surgery has enabled urologic surgeons to perform urinary diversions intracorporeally. ${ }^{101}$ Intracorporeal urinary diversion has the potential benefits of a smaller incision, reduced pain, decreased bowel exposure, and reduced risk of fluid imbalance. A study by the International Robotic Cystectomy Consortium found that patients undergoing intracorporeal diversion after RARC were at a lower risk of 90-day postoperative complication. ${ }^{102}$
Since radical cystectomy represents a cancer surgery, oncological outcomes remain a primary concern. Only few series of minimally invasive radical cystectomy with long term oncological follow-up have been reported to date, with encouraging results. ${ }^{103-105}$ Concerns regarding the pattern of recurrence after RARC, with one study showing more frequent extra-pelvic lymph node locations and peritoneal carcinomatosis in RARC patients compared to open surgery patients. ${ }^{106}$ In this regard, studies on laparoscopic series have advocated a potential risk associated with the use of pneumoperitoneum. ${ }^{107}$ Nevertheless, a study on a recent large series of patients who underwent RARC with intracorporeal urinary diversion at nine different institutions did not identify unusual recurrence patterns. ${ }^{108}$

\section{Kidney cancer}

Despite a rising incidence, the mortality of RCC in developed countries has been stable over the last decade. ${ }^{109}$ This phenomenon can be explained by the significant advances in the management of the disease, including refinements in renal biopsy techniques, ${ }^{110}$ implementation of active surveillance protocols, ${ }^{11}$ and adoption of minimally invasive nephron-sparing surgery procedures. ${ }^{112}$ This has resulted into a paradigm shift, which is the idea of tailoring the treatment to each specific case with the ultimate aim of achieving the best oncological outcome and the maximal functional preservation. This process has been facilitated by the application of new technologies, allowing a better surgical planning, within the realm of "precision surgery".

\section{Expanding indications of nephron-sparing surgery and evolving role of robotic partial nephrectomy}

Current clinical practice guidelines recommend partial nephrectomy (PN) as the gold standard treatment for small (clinical T1a) renal masses, given the advantages of nephron-sparing surgery over radical nephrectomy in terms of renal function preservation. ${ }^{113,114}$ Emerging data from centers of excellence as well as from national databases and meta-analyses have demonstrated oncological efficacy for larger masses (cT1b, cT2) with benefits in terms of renal functional preservation. ${ }^{115-117}$ On the other hand, an overarching survival benefit from PN is 


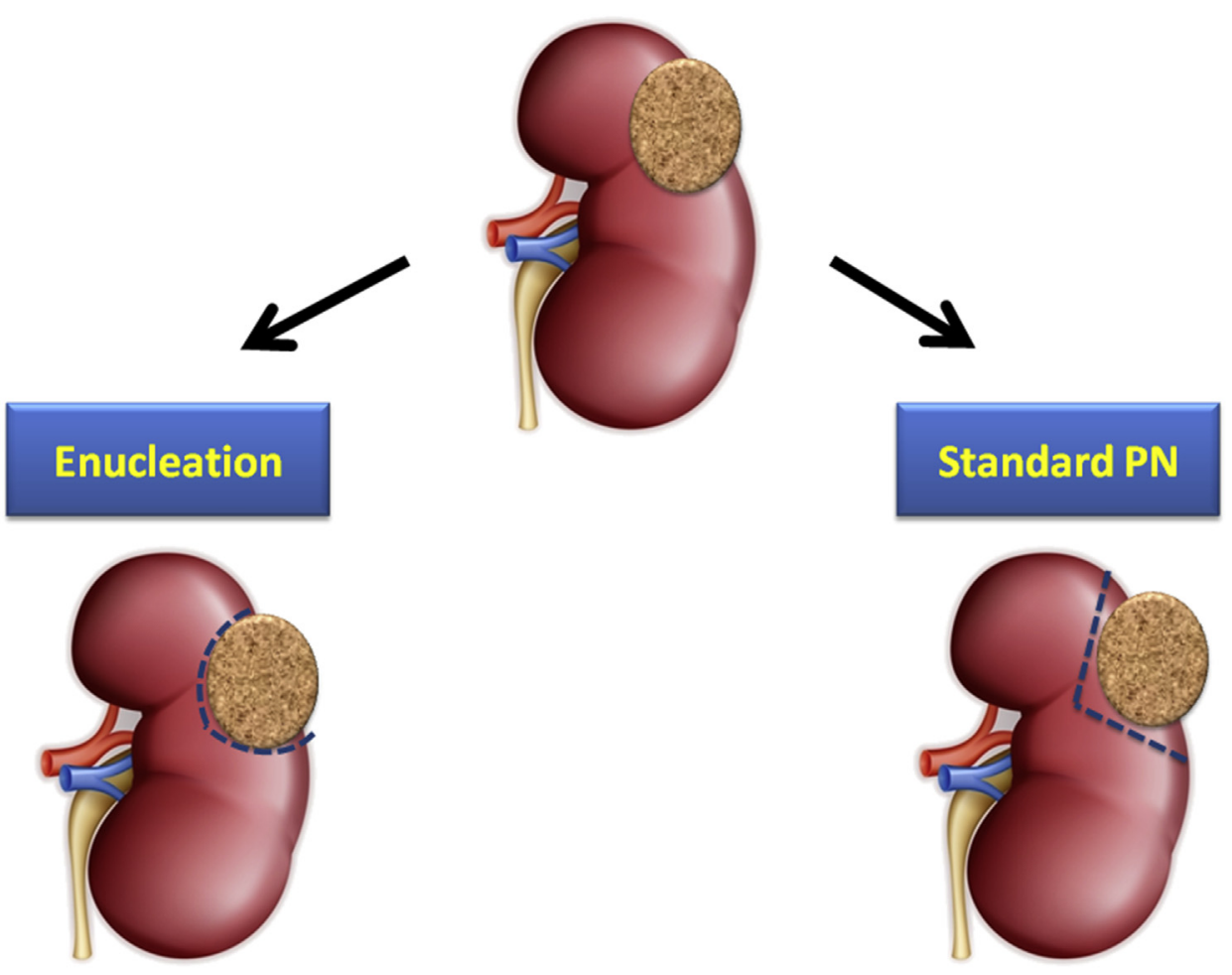

Figure 7. Illustration of enucleation versus standard partial nephrectomy for the resection of renal tumors (dashed line $=$ surgical plan of resection).

more controversial with several retrospective and meta analyses suggesting a survival benefit while the sole randomized clinical (which closed due to poor enrollment and was thus underpowered) trial failing to demonstrate a survival benefit for partial nephrectomy despite improved renal functional outcomes in the partial nephrectomy arm. $^{118,119}$

Despite the oncological equivalence to radical nephrectomy and renal functional benefit, PN has been regarded as a higher risk procedure with increased risk of urinary fistulae and procedure specific complications. This paradigm may be shifting however, with the increasing adoption of the robotic platform. Recent data suggest that robotic technology may enable surgeons across different practice settings to perform nephron-sparing surgery more frequently. ${ }^{120}$

The robotic approach offers the option of a minimally invasive PN recapitulating the safety and effectiveness of the open technique, which can still be regarded as the reference standard. The standardization of each surgical step has allowed for optimization of robotic PN procedure. ${ }^{121}$ With increasing surgical experience, indications for robotic PN have significantly expanded to include more demanding clinical scenarios, such as completely intraparenchymal tumors, ${ }^{122}$ hilar tumors, ${ }^{123}$ and patients with previous ipsilateral nephron-sparing procedure. ${ }^{124}$

Moreover, current evidence suggests that robotic PN can translate into better outcomes than conventional laparoscopic PN. A recent meta-analysis of 25 studies (including almost 5000 patients) showed that patients treated with robotics presented larger (WMD $0.17 \mathrm{~cm}$, $\mathrm{p}=0.001$ ) and more complex (WMD 0.59 RENAL score, $\mathrm{p}=0.002$ ) tumors. Nevertheless, robotic surgery was associated with a decreased likelihood of conversion (RR 0.36, $\mathrm{p}<0.001$ ), and lower risk of complications (RR 0.84, $\mathrm{p}=0.007)$ and positive margins (RR 0.53, p < 0.001), and shorter warm ischemia time (WMD $4.3 \mathrm{~min}$, $\mathrm{p}<0.001) .{ }^{125}$ Thus, robotics might replace laparoscopy as the most common minimally invasive approach for PN whenever the necessary technology is available. ${ }^{126}$ However, in the hands of expert surgeons and with the aid of last new tools, such as 3D imaging and the ETHOS chair a more ergonomic position for the surgeon can facilitate the pure laparoscopy approach. ${ }^{127}$

From the standpoint of the surgical technique, the recent debate has been primarily focused on the management of the renal hilum. The recognized role of warm ischemia time as a modifiable factor impacting the postoperative renal functional outcome ${ }^{128}$ prompted several groups to explore the feasibility and safety of "zero-ischemia" (off clamp) and "minimal ischemia" (selective clamping) techniques. ${ }^{129}$ With the increasing awareness regarding the preservation of healthy parenchyma as a major determinant of postoperative renal function, ${ }^{130}$ another matter of debate has become the tumor resection technique. While the standard PN procedure implies the resection of a rim of renal 
Table 8

Focal therapy for kidney cancer: overview of available techniques. ${ }^{132-137}$

\begin{tabular}{|c|c|c|c|c|c|c|c|c|}
\hline Technique & Commercial names & Mechanism & Technique & $\begin{array}{l}\text { Major } \\
\text { complication } \\
\text { rate, } \%\end{array}$ & $\begin{array}{l}\text { Failure } \\
\text { rate, } \%\end{array}$ & FU, months & $\begin{array}{l}\text { Oncological } \\
\text { outcomes }\end{array}$ & Current status \\
\hline CRYO & $\begin{array}{l}\text { Endocare }^{\circledR} \\
\text { (Healthtronics); } \\
\text { Visual-ICE }^{\circledR} \text { (Galil) }\end{array}$ & $\begin{array}{l}\text { Rapid cooling } \\
\text { leading to cell } \\
\text { necrosis }\end{array}$ & $\begin{array}{l}\text { Perc (CT guided); } \\
\text { Lap (US guided) }\end{array}$ & $0-9.5$ & $1.5-13$ & $20-97.9$ & $\begin{array}{l}\text { RFS: } 77 \% \\
\text { DFS: } 85-97 \% \\
\text { CSS: } 98.5-100 \%\end{array}$ & $\begin{array}{l}\text { Established in } \\
\text { clinical practice }\end{array}$ \\
\hline RFA & $\begin{array}{l}\text { LeVeen }^{\circledR} \text { (Boston); } \\
\text { Cool-tip }^{\circledR} \text { (Covidien); } \\
\text { RITA StarBust }^{\circledR} \\
\text { (Angiodynamics) }\end{array}$ & $\begin{array}{l}\text { Heat conduction } \\
\text { inducing cellular } \\
\text { death }\end{array}$ & $\begin{array}{l}\text { Perc (CT guided } \\
\text { or MRI guided); } \\
\text { Lap (US guided) }\end{array}$ & 8 & $2.5-10$ & $27-65.6$ & $\begin{array}{l}\text { RFS: } 88-94.2 \% \\
\text { DFS: } 61.9-90.6 \% \\
\text { CSS: } 96.8-100 \%\end{array}$ & \\
\hline MWA & $\begin{array}{l}\text { Acculis }^{\circledR} \\
\text { (Angiodynamics); } \\
\text { Evident }^{\circledR} \text { (Medtronic); } \\
\text { KY2000 } \\
\text { (Kangyou Medical) }\end{array}$ & $\begin{array}{l}\text { Kinetic energy } \\
\text { transformed into } \\
\text { heat, leading to } \\
\text { cell death }\end{array}$ & $\begin{array}{l}\text { Perc (CT guided); } \\
\text { Lap (US guided) }\end{array}$ & $2-3$ & $3-4.2 \%$ & $6-32$ & $\begin{array}{l}\text { RFS: } 62-91.3 \% \\
\text { DFS: } 92.3 \% \\
\text { CSS: } 85.7-100 \%\end{array}$ & Investigational \\
\hline IRE & $\begin{array}{l}\text { Naonoknife }^{\circledR} \\
\text { (Angiodynamics) }\end{array}$ & $\begin{array}{l}\text { Electropulses } \\
\text { creating nanoscale } \\
\text { defects in cellular } \\
\text { membrane }\end{array}$ & $\begin{array}{l}\text { Perc (CT or US } \\
\text { guided); }\end{array}$ & 0 & 10 & $1-10$ & RFS: 90 & \\
\hline
\end{tabular}

$\mathrm{CRYO}=$ cryotherapy; RFA = radiofrequency ablation; MWA = microwave ablation; IRE = irreversible electroporation; FU = follow-up; RFS = recurrence free survival; DFS = disease free survival; CSS = cancer specific survival.

parenchyma around the tumor, some groups have advocated "enucleation" techniques ${ }^{131}$ with the aim of maximizing preservation of nephrons while effectively removing the cancer (Fig. 7).

\section{Tumor ablation techniques}

With the aim of further minimizing the surgical morbidity, focal kidney ablation can be offered as an effective minimally invasive nephron-sparing treatment option. Several ablative technologies have been investigated to date; cryoablation and radiofrequency ablation (RFA) certainly represents the two modalities that have been most extensively implemented in clinical practice, ${ }^{132}$ whereas other ablative procedures (microwave ablation, electroporation) are still investigational ${ }^{133-136}$ (Table 8).

Overall, probe-ablative therapy provides an attractive nephron-sparing treatment for small renal masses in older patients with significant medical co-morbidities who are poor candidates for standard extirpative surgery. In well selected patients, kidney ablation can offer several advantages, including improved patient procedural tolerance, faster recovery, preservation of renal function, and reduction in the risk of complications. It is likely that outcomes associated with ablative modalities will improve with further advances in patient selection, technology and application. Emerging data suggest that for both cryoablation and RFA, patients with non-clear cell and lower grade histologies may have improved outcomes. ${ }^{137}$ Patient counseling about thermal ablation should include a discussion of the risks of local recurrence, and potential need for re-intervention. Newer energy-ablative modalities have the potential to become additional nephron-sparing options, but further investigation is needed.

\section{Conclusions}

Over the past two decades, the paradigm of urooncological surgery has moved away from the obsolete principle of exclusively radical "one-size-fits-all" procedures. The current surgical therapy of the most common genitourinary cancers aims to combine the maximal oncological efficacy with the minimal impact on patient's quality of life and functionality. A better knowledge of anatomy and cancer biology coupled with better diagnostic instruments allowed to improve surgical indications, to optimize surgical planning, and to tailor the surgical procedure to each specific patient. The application of novel technologies (robotic surgery, focal therapy, new imaging systems) have facilitated a minimally invasive approach in most of urologic cancer patients. We entered an era of "precision surgery"; nevertheless, the management of patients with genitourinary cancers remains suboptimal, and further translational research is needed to address many unmet needs in this field.

\section{Conflicts of interest}

The authors have no conflict of interest.

\section{References}

1. Sosnowski R, Kulpa M, Kosowicz M, et al. Basic methods for the assessment of the health related quality of life in uro-oncological patients. Minerva Urol Nefrol 2016 Sep 28. [Epub ahead of print] PubMed PMID: 27681491.

2. Wong MC, Goggins WB, Wang HH, et al. Global incidence and mortality for prostate cancer: analysis of temporal patterns and trends in 36 countries. Eur Urol 2016 Jun 8. http://dx.doi.org/ 10.1016/j.eururo.2016.05.043 pii: S0302-2838(16)30251-2. [Epub ahead of print]. 
3. Weinreb JC, Barentsz JO, Choyke PL, et al. PI-RADS prostate imaging - reporting and data system: 2015, version 2. Eur Urol 2016 Jan; 69(1):16-40.

4. Morlacco A, Sharma V, Viers BR, et al. The incremental role of magnetic resonance imaging for prostate cancer staging before radical prostatectomy. Eur Urol 2016 Aug 28. http://dx.doi.org/10.1016/ j.eururo.2016.08.015 pii: S0302-2838(16)30482-1. [Epub ahead of print] PubMed PMID: 27576750.

5. Weerakoon M, Papa N, Lawrentschuk N, et al. The current use of active surveillance in an Australian cohort of men: a pattern of care analysis from the Victorian Prostate Cancer Registry. BJU Int 2015 Apr;115(Suppl. 5):50-6.

6. Zargar H, Giannarini G, Loeb S, Dasgupta P, Murphy DG, Ficarra V. Active surveillance in prostate cancer: a critical review. Minerva Urol Nefrol 2015 Sep;67(3):247-61.

7. Boström PJ, Bjartell AS, Catto JW, et al. Genomic predictors of outcome in prostate cancer. Eur Urol 2015 Dec;68(6):1033-44.

8. Chang SL, Kibel AS, Brooks JD, Chung BI. The impact of robotic surgery on the surgical management of prostate cancer in the USA. BJU Int 2015 Jun;115(6):929-36.

9. Barbash GI, Friedman B, Glied SA, Steiner CA. Factors associated with adoption of robotic surgical technology in US hospitals and relationship to radical prostatectomy procedure volume. Ann Surg 2014 Jan;259(1):1-6.

10. Montorsi F, Wilson TG, Rosen RC, et al. Best practices in robotassisted radical prostatectomy: recommendations of the Pasadena Consensus Panel. Eur Urol 2012 Sep;62(3):368-81.

11. Laviana AA, Williams SB, King ED, Chuang RJ, Hu JC. Robot assisted radical prostatectomy: the new standard? Minerva Urol Nefrol 2015 Mar;67(1):47-53.

12. Porpiglia F, Manfredi M, Mele F, et al. Diagnostic pathway with multiparametric magnetic resonance imaging versus standard pathway: results from a randomized prospective study in biopsy-naïve patients with suspected prostate cancer. Eur Urol 2016 Aug 27. http:// dx.doi.org/10.1016/j.eururo.2016.08.041 pii: S0302-2838(16)305097. [Epub ahead of print].

13. Miano R, Asimakopoulos AD, Da Silva RD, et al. Focal therapy for prostate cancer: current status and future perspectives. Minerva Urol Nefrol 2015 Sep;67(3):263-80.

14. Walz J, Epstein JI, Ganzer R, et al. A critical analysis of the current knowledge of surgical anatomy of the prostate related to optimisation of cancer control and preservation of continence and erection in candidates for radical prostatectomy: an update. Eur Urol 2016;70(2):301-11.

15. Ou YC, Yang CK, Wang J, et al. The trifecta outcome in 300 consecutive cases of robotic-assisted laparoscopic radical prostatectomy according to D'Amico risk criteria. Eur J Surg Oncol 2013 Jan; 39(1):107-13.

16. Wagner AA, Cheng PJ, Carneiro A, et al. Clinical use of expanded prostate cancer index composite for clinical practice to assess patient reported prostate cancer quality of life following robot-assisted radical prostatectomy. J Urol 2016 Jul 27. http://dx.doi.org/ 10.1016/j.juro.2016.07.080 pii: S0022-5347(16)30925-9.

17. Heesakkers J, Farag F, Bauer RM, Sandhu J, De Ridder D, Stenzl A. Pathophysiology and contributing factors in postprostatectomy incontinence: a review. Eur Urol 2016 Oct 6. http://dx.doi.org/ 10.1016/j.eururo.2016.09.031 pii: S0302-2838(16) $\overline{30666-2 \text {. [Epub }}$ ahead of print].

18. Friedlander DF, Alemozaffar M, Hevelone ND, Lipsitz SR, Hu JC. Stepwise description and outcomes of bladder neck sparing during robot-assisted laparoscopic radical prostatectomy. J Urol 2012 Nov; 188(5): 1754-60.

19. Lei Y, Alemozaffar M, Williams SB, et al. Athermal division and selective suture ligation of the dorsal vein complex during robotassisted laparoscopic radical prostatectomy: description of technique and outcomes. Eur Urol 2011 Feb;59(2):235-43.

20. Patel VR, Coelho RF, Palmer KJ, Rocco B. Periurethral suspension stitch during robot-assisted laparoscopic radical prostatectomy: description of the technique and continence outcomes. Eur Urol 2009 Sep;56(3):472-8.

21. Nguyen HG, Punnen S, Cowan JE, et al. A randomized study of intraoperative autologous retropubic urethral sling on urinary control after robotic assisted radical prostatectomy. J Urol 2016 Sep 28. http://dx.doi.org/10.1016/j.juro.2016.08.122 pii: $\quad$ S0022-5347(16) 31400-8.

22. Bahler CD, Sundaram CP, Kella N, et al. A parallel randomized clinical trial examining the return of urinary continence after robotassisted radical prostatectomy with or without a small intestinal submucosa bladder neck sling. J Urol 2016 Jul;196(1):179-84.

23. Porpiglia F, Bertolo R, Manfredi M, et al. Total anatomical reconstruction during robot-assisted radical prostatectomy: implications on early recovery of urinary continence. Eur Urol 2016 Mar;69(3): 485-95.

24. Lee DI, Wedmid A, Mendoza P, et al. Bladder neck plication stitch: a novel technique during robot-assisted radical prostatectomy to improve recovery of urinary continence. J Endourol 2011 Dec; 25(12):1873-7.

25. Student Jr V, Vidlar A, Grepl M, Hartmann I, Buresova E, Student V. Advanced reconstruction of vesicourethral support (ARVUS) during robot-assisted radical prostatectomy: one-year functional outcomes in a two-group randomised controlled trial. Eur Urol 2016 Jun 6. http://dx.doi.org/10.1016/j.eururo.2016.05.032 pii: S0302-2838(16) 30201-9.

26. Jeong CW, Lee JK, Oh JJ, et al. Effects of new 1-step posterior reconstruction method on recovery of continence after robotassisted laparoscopic prostatectomy: results of a prospective, single-blind, parallel group, randomized, controlled trial. J Urol 2015 Mar;193(3):935-42.

27. Dal Moro F, Crestani A, Valotto C, Zattoni F. CORPUS - novel Complete Reconstruction of the Posterior Urethral Support after robotic radical prostatectomy: preliminary data of very early continence recovery. Urology 2014 Mar;83(3):641-7.

28. Hurtes X, Rouprêt M, Vaessen C, et al. Anterior suspension combined with posterior reconstruction during robot-assisted laparoscopic prostatectomy improves early return of urinary continence: a prospective randomized multicentre trial. BJU Int 2012 Sep; 110(6):875-83.

29. Coelho RF, Chauhan S, Orvieto MA, et al. Influence of modified posterior reconstruction of the rhabdosphincter on early recovery of continence and anastomotic leakage rates after robot-assisted radical prostatectomy. Eur Urol 2011 Jan;59(1):72-80.

30. Lim SK, Kim KH, Shin TY, et al. Retzius-sparing robot-assisted laparoscopic radical prostatectomy: combining the best of retropubic and perineal approaches. BJU Int 2014 Aug;114(2):236-44.

31. Kojima Y, Takahashi N, Haga N, et al. Urinary incontinence after robot-assisted radical prostatectomy: pathophysiology and intraoperative techniques to improve surgical outcome. Int J Urol 2013 Nov; 20(11):1052-63.

32. Rassweiler J, Laguna P, Chlosta P, et al. ESUT expert group on laparoscopy proposes uniform terminology during radical prostatectomy: we need to speak the same language. Eur Urol 2013 Jul;64(1): 97-100.

33. Ficarra V, Novara G, Ahlering TE, et al. Systematic review and metaanalysis of studies reporting potency rates after robot-assisted radical prostatectomy. Eur Urol 2012 Sep;62(3):418-30.

34. Salonia A, Castagna G, Capogrosso P, Castiglione F, Briganti A, Montorsi F. Prevention and management of post prostatectomy erectile dysfunction. Transl Androl Urol 2015 Aug;4(4):421-37.

35. Tewari AK, Srivastava A, Huang MW, et al. Anatomical grades of nerve sparing: a risk-stratified approach to neural-hammock sparing during robot-assisted radical prostatectomy (RARP). BJU Int 2011 Sep;108(6 Pt 2):984-92.

36. Schatloff O, Chauhan S, Sivaraman A, Kameh D, Palmer KJ, Patel VR. Anatomic grading of nerve sparing during robot-assisted radical prostatectomy. Eur Urol 2012 Apr;61(4):796-802. 
37. Kowalczyk KJ, Huang AC, Hevelone ND, et al. Stepwise approach for nerve sparing without countertraction during robot-assisted radical prostatectomy: technique and outcomes. Eur Urol 2011 Sep; 60(3):536-47.

38. Galfano A, Di Trapani D, Sozzi F, et al. Beyond the learning curve of the Retzius-sparing approach for robot-assisted laparoscopic radical prostatectomy: oncologic and functional results of the first $200 \mathrm{pa}-$ tients with $\geq 1$ year of follow-up. Eur Urol 2013 Dec;64(6):974-80.

39. Beyer B, Schlomm T, Tennstedt P, et al. A feasible and time-efficient adaptation of NeuroSAFE for da Vinci robot-assisted radical prostatectomy. Eur Urol 2014 Jul;66(1):138-44.

40. Patel VR, Samavedi S, Bates AS, et al. Dehydrated human amnion/ chorion membrane allograft nerve wrap around the prostatic neurovascular bundle accelerates early return to continence and potency following robot-assisted radical prostatectomy: propensity scorematched analysis. Eur Urol 2015 Jun;67(6):977-80.

41. Greco F, Cadeddu JA, Gill IS, et al. Current perspectives in the use of molecular imaging to target surgical treatments for genitourinary cancers. Eur Urol 2014 May;65(5):947-64.

42. Abbou CC, Hoznek A, Salomon L, et al. Laparoscopic radical prostatectomy with a remote controlled robot. J Urol 2001 Jun;165(6 Pt 1):1964-6.

43. Sooriakumaran P, Haendler L, Nyberg T, et al. Biochemical recurrence after robot-assisted radical prostatectomy in a European single-centre cohort with a minimum follow-up time of 5 years. Eur Urol 2012 Nov;62(5):768-74.

44. Abdollah F, Sood A, Sammon JD, et al. Long-term cancer control outcomes in patients with clinically high-risk prostate cancer treated with robot-assisted radical prostatectomy: results from a multi-institutional study of 1100 patients. Eur Urol 2015 Sep; 68(3):497-505.

45. Diaz M, Peabody JO, Kapoor V, et al. Oncologic outcomes at 10 years following robotic radical prostatectomy. Eur Urol 2015 Jun; 67(6):1168-76.

46. Abdel Raheem A, Kim DK, Santok GD, et al. Stratified analysis of 800 Asian patients after robot-assisted radical prostatectomy with a median 64 months of follow up. Int J Urol 2016 Sep;23(9):765-74.

47. Suardi N, Ficarra V, Willemsen P, et al. Long-term biochemical recurrence rates after robot-assisted radical prostatectomy: analysis of a single-center series of patients with a minimum follow-up of 5 years. Urology 2012 Jan;79(1):133-8.

48. Billia M, Elhage O, Challacombe B, et al. Oncological outcomes of robotic-assisted radical prostatectomy after more than 5 years. World J Urol 2014 Apr;32(2):413-8.

49. Liss MA, Lusch A, Morales B, et al. Robot-assisted radical prostatectomy: 5-year oncological and biochemical outcomes. J Urol 2012 Dec; $\mathbf{1 8 8}(6): 2205-10$.

50. Hu JC, Gandaglia G, Karakiewicz PI, et al. Comparative effectiveness of robot-assisted versus open radical prostatectomy cancer control. Eur Urol 2014 Oct;66(4):666-72.

51. Haglind E, Carlsson S, Stranne J, et al. Urinary incontinence and erectile dysfunction after robotic versus open radical prostatectomy: a prospective, controlled, nonrandomised trial. Eur Urol 2015 Aug; 68(2):216-25.

52. Leow JJ, Chang SL, Meyer CP, et al. Robot-assisted versus open radical prostatectomy: a contemporary analysis of an all-payer discharge database. Eur Urol 2016 Feb 10. http://dx.doi.org/ 10.1016/j.eururo.2016.01.044 pii: S0302-2838(16)00163-9.

53. Seo HJ, Lee NR, Son SK, Kim DK, Rha KH, Lee SH. Comparison of robot-assisted radical prostatectomy and open radical prostatectomy outcomes: a systematic review and meta-analysis. Yonsei Med J 2016 Sep;57(5):1165-77.

54. Yaxley JW, Coughlin GD, Chambers SK, et al. Robot-assisted laparoscopic prostatectomy versus open radical retropubic prostatectomy: early outcomes from a randomised controlled phase 3 study. Lancet 2016 Sep 10;388(10049):1057-66.
55. Hu JC, O'Malley P, Chughtai B, et al. Comparative effectiveness of cancer control and survival after robot-assisted versus open radical prostatectomy. J Urol 2016 Oct 5. http://dx.doi.org/10.1016/ j.juro.2016.09.115 pii: S0022-5347(16)31441-0. [Epub ahead of print].

56. Thompson JE, Egger S, Böhm M, et al. Superior quality of life and improved surgical margins are achievable with robotic radical prostatectomy after a long learning curve: a prospective singlesurgeon study of 1552 consecutive cases. Eur Urol 2014 Mar; 65(3):521-31.

57. Tosoian JJ, Gorin MA, Ross AE, Pienta KJ, Tran PT, Schaeffer EM. Oligometastatic prostate cancer: definitions, clinical outcomes, and treatment considerations. Nat Rev Urol 2016 Oct 11. http:// dx.doi.org/10.1038/nrurol.2016.175 [Epub ahead of print] Review. PubMed PMID: 27725639.

58. Culp SH, Schellhammer PF, Williams MB. Might men diagnosed with metastatic prostate cancer benefit from definitive treatment of the primary tumor? A SEER-based study. Eur Urol 2014 Jun; 65(6): 1058-66.

59. Gratzke C, Engel J, Stief CG. Role of radical prostatectomy in metastatic prostate cancer: data from the Munich Cancer Registry. Eur Urol 2014 Sep;66(3):602-3.

60. Gandaglia G, Fossati N, Stabile A, et al. Radical prostatectomy in men with oligometastatic prostate cancer: results of a singleinstitution series with long-term follow-up. Eur Urol 2016 Aug 26. http://dx.doi.org/10.1016/j.eururo.2016.08.040 pii: S0302-2838(16) 30508-5. [Epub ahead of print] PubMed PMID: 27574820.

61. Abdollah F, Briganti A, Montorsi F, et al. Contemporary role of salvage lymphadenectomy in patients with recurrence following radical prostatectomy. Eur Urol 2015 May;67(5):839-49.

62. Evangelista L, Briganti A, Fanti S, et al. New clinical indications for (18)F/(11)C-choline, new tracers for positron emission tomography and a promising hybrid device for prostate cancer staging: a systematic review of the literature. Eur Urol 2016 Jul;70(1): $161-75$.

63. Suardi N, Gandaglia G, Gallina A, et al. Long-term outcomes of salvage lymph node dissection for clinically recurrent prostate cancer: results of a single-institution series with a minimum follow-up of 5 years. Eur Urol 2015 Feb;67(2):299-309.

64. Osmonov DK, Aksenov AV, Trick D, et al. Cancer-specific and overall survival in patients with recurrent prostate cancer who underwent salvage extended pelvic lymph node dissection. BMC Urol $2016 \mathrm{Sep}$ 6;16(1):56. http://dx.doi.org/10.1186/s12894-016-0173-3.

65. Winter A, Henke RP, Wawroschek F. Targeted salvage lymphadenectomy in patients treated with radical prostatectomy with biochemical recurrence: complete biochemical response without adjuvant therapy in patients with low volume lymph node recurrence over a long-term follow-up. BMC Urol 2015 Feb 21;15:10.

66. Montorsi F, Gandaglia G, Fossati N, et al. Robot-assisted salvage lymph node dissection for clinically recurrent prostate cancer. Eur Urol 2016 Sep 3. http://dx.doi.org/10.1016/j.eururo.2016.08.051 pii: S0302-2838(16)30524-3.

67. de Castro Abreu AL, Fay CE, Park D, et al. Robotic salvage retroperitoneal and pelvic lymph node dissection for "Node-only" recurrent prostate cancer: technique and initial series. BJU Int 2016 Dec 15 http://dx.doi.org/10.1111/bju.13741 [Epub ahead of print].

68. Donaldson IA, Alonzi R, Barratt D, et al. Focal therapy: patients, interventions, and outcomes - a report from a consensus meeting. Eur Urol 2015 Apr;67(4):771-7.

69. De Visschere PJ, Briganti A, Fütterer JJ, et al. Role of multiparametric magnetic resonance imaging in early detection of prostate cancer. Insights Imaging 2016 Apr;7(2):205-14.

70. Valerio M, Cerantola Y, Eggener SE, et al. New and established technology in focal ablation of the prostate: a systematic review. Eur Urol 2017 Jan;71(1):17-34.

71. Azzouzi AR, Vincendeau S, Barret E, et al. Padeliporfin vasculartargeted photodynamic therapy versus active surveillance in men 
with low-risk prostate cancer (CLIN1001 PCM301): an open-label, phase 3, randomised controlled trial. Lancet Oncol 2016 Dec 19. http://dx.doi.org/10.1016/S1470-2045(16)30661-1 pii: S1470-2045 (16)30661-1.

72. Burger M, Catto JW, Dalbagni G, et al. Epidemiology and risk factors of urothelial bladder cancer. Eur Urol 2013 Feb;63(2):234-41.

73. Babjuk M, Böhle A, Burger M, et al. EAU guidelines on non-muscleinvasive urothelial carcinoma of the bladder: update 2016. Eur Urol 2016 Jun 17. http://dx.doi.org/10.1016/j.eururo.2016.05.041 pii: S0302-2838(16)30249-4. [Epub ahead of print] PubMed PMID: 27324428.

74. Gakis G, Efstathiou J, Lerner SP, et al. ICUD-EAU International Consultation on Bladder Cancer 2012: radical cystectomy and bladder preservation for muscle-invasive urothelial carcinoma of the bladder. Eur Urol 2013 Jan;63(1):45-57.

75. Bach T, Muschter R, Herrmann TR, et al. Technical solutions to improve the management of non-muscle-invasive transitional cell carcinoma: summary of a European Association of Urology Section for Uro-Technology (ESUT) and Section for Uro-Oncology (ESOU) expert meeting and current and future perspectives. BJU Int 2015 Jan;115(1):14-23.

76. Stenzl A, Burger M, Fradet Y, et al. Hexaminolevulinate guided fluorescence cystoscopy reduces recurrence in patients with nonmuscle invasive bladder cancer. J Urol 2010 Nov;184(5):1907-13.

77. Burger M, Grossman HB, Droller M, et al. Photodynamic diagnosis of non-muscle-invasive bladder cancer with hexaminolevulinate cystoscopy: a meta-analysis of detection and recurrence based on raw data. Eur Urol 2013 Nov;64(5):846-54.

78. Schumacher MC, Holmäng S, Davidsson T, Friedrich B, Pedersen J, Wiklund NP. Transurethral resection of non-muscle-invasive bladder transitional cell cancers with or without 5-aminolevulinic acid under visible and fluorescent light: results of a prospective, randomised, multicentre study. Eur Urol 2010 Feb;57(2):293-9.

79. Lerner SP, Liu H, Wu MF, Thomas YK, Witjes JA. Fluorescence and white light cystoscopy for detection of carcinoma in situ of the urinary bladder. Urol Oncol 2012 May-Jun;30(3):285-9.

80. Herr HW, Donat SM. A comparison of white-light cystoscopy and narrow-band imaging cystoscopy to detect bladder tumour recurrences. BJU Int 2008 Nov;102(9):1111-4.

81. Zheng C, Lv Y, Zhong Q, Wang R, Jiang Q. Narrow band imaging diagnosis of bladder cancer: systematic review and meta-analysis. BJU Int 2012 Dec;110(11 Pt B):E680-7.

82. Kang W, Cui Z, Chen Q, Zhang D, Zhang H, Jin X. Narrow band imaging-assisted transurethral resection reduces the recurrence risk of non-muscle invasive bladder cancer: a systematic review and meta-analysis. Oncotarget 2016 Nov 3. http://dx.doi.org/10.18632/ oncotarget.13054 [Epub ahead of print].

83. Naito S, Algaba F, Babjuk M, et al. The Clinical Research Office of the Endourological Society (CROES) multicentre randomised trial of narrow band imaging-assisted transurethral resection of bladder tumour (TURBT) versus conventional white light imaging-assisted TURBT in primary non-muscle-invasive bladder cancer patients: trial protocol and 1-year results. Eur Urol 2016 Sep;70(3):506-15. http:// dx.doi.org/10.1016/j.eururo.2016.03.053.

84. Adams W, Wu K, Liu JJ, Hsiao ST, Jensen KC, Liao JC. Comparison of 2.6- and 1.4-mm imaging probes for confocal laser endomicroscopy of the urinary tract. $J$ Endourol 2011 Jun;25(6):917-21.

85. Sonn GA, Jones SN, Tarin TV, et al. Optical biopsy of human bladder neoplasia with in vivo confocal laser endomicroscopy. J Urol 2009 Oct;182(4):1299-305.

86. Goh AC, Tresser NJ, Shen SS, Lerner SP. Optical coherence tomography as an adjunct to white light cystoscopy for intravesical real-time imaging and staging of bladder cancer. Urology $2008 \mathrm{Jul}$; 72(1):133-7.

87. Manyak MJ, Gladkova ND, Makari JH, et al. Evaluation of superficial bladder transitional-cell carcinoma by optical coherence tomography. J Endourol 2005 Jun;19(5):570-4.
88. Alfred Witjes J, Lebret T, Comperat EM, et al. Updated 2016 EAU guidelines on muscle-invasive and metastatic bladder cancer. Eur Urol 2016 Jun 30. http://dx.doi.org/10.1016/j.eururo.2016.06.020 pii: S0302-2838(16)30290-1.

89. Roth B, Thalmann GN. Standard cystectomy fits all: truth or myth? Transl Androl Urol 2015 Jun;4(3):254-60.

90. Mertens LS, Meijer RP, de Vries RR, et al. Prostate sparing cystectomy for bladder cancer: 20-year single center experience. J Urol 2014 May;191(5):1250-5.

91. Ong CH, Schmitt M, Thalmann GN, Studer UE. Individualized seminal vesicle sparing cystoprostatectomy combined with ileal orthotopic bladder substitution achieves good functional results. J Urol 2010 Apr;183(4):1337-41.

92. Schoenberg MP, Walsh PC, Breazeale DR, Marshall FF, Mostwin JL, Brendler CB. Local recurrence and survival following nerve sparing radical cystoprostatectomy for bladder cancer: 10-year followup. J Urol $1996 \mathrm{Feb} ; \mathbf{1 5 5}(2): 490-4$.

93. Kessler TM, Burkhard FC, Perimenis P, et al. Attempted nerve sparing surgery and age have a significant effect on urinary continence and erectile function after radical cystoprostatectomy and ileal orthotopic bladder substitution. J Urol 2004 Oct;172(4 Pt 1):1323-7.

94. Ali-El-Dein B, Mosbah A, Osman Y, et al. Preservation of the internal genital organs during radical cystectomy in selected women with bladder cancer: a report on 15 cases with long term follow-up. Eur $J$ Surg Oncol 2013 Apr;39(4):358-64.

95. Bhatta Dhar N, Kessler TM, Mills RD, Burkhard F, Studer UE. Nerve-sparing radical cystectomy and orthotopic bladder replacement in female patients. Eur Urol 2007 Oct;52(4):1006-14.

96. Menon M, Hemal AK, Tewari A, et al. Nerve-sparing robot-assisted radical cystoprostatectomy and urinary diversion. BJU Int 2003;92: 232-6.

97. Al-Tartir T, Raza S, Alotaibi M, et al. Robot-assisted surgical approach to bladder cancer: a decade of progress!. Minerva Urol Nefrol 2015 Mar;67(1):55-63.

98. Xia L, Wang X, Xu T, et al. Robotic versus open radical cystectomy: an updated systematic review and meta-analysis. PLoS One 2015 Mar 31;10(3):e0121032.

99. Tan WS, Khetrapal P, Tan WP, Rodney S, Chau M, Kelly JD. Robotic assisted radical cystectomy with extracorporeal urinary diversion does not show a benefit over open radical cystectomy: a systematic review and meta-analysis of randomised controlled trials. PLoS One 2016 Nov 7;11(11):e0166221. http://dx.doi.org/10.1371/ journal.pone.0166221.

100. Smith ND, Castle EP, Gonzalgo ML, et al. The RAZOR (randomized open vs robotic cystectomy) trial: study design and trial update. $B J U$ Int $2015 \mathrm{Feb} ; \mathbf{1 1 5}(2): 198-205$.

101. Dal Moro F, Haber GP, Wiklund P, et al. Robotic intracorporeal urinary diversion: practical review of current surgical techniques. Minerva Urol Nefrol 2017 Feb;69(1):14-25. http://dx.doi.org/ 10.23736/S0393-2249.16.02780-6 PubMed PMID: 28009143.

102. Ahmed K, Khan SA, Hayn MH, et al. Analysis of intracorporeal compared with extracorporeal urinary diversion after robot-assisted radical cystectomy: results from the International Robotic Cystectomy Consortium. Eur Urol 2014;65(2):340-7.

103. Albisinni S, Rassweiler J, Abbou CC, et al. Long-term analysis of oncological outcomes after laparoscopic radical cystectomy in Europe: results from a multicentre study by the European Association of Urology (EAU) section of uro-technology. BJU Int 2015;115(6):937-45.

104. Khan MS, Elhage O, Challacombe B, et al. Long-term outcomes of robot-assisted radical cystectomy for bladder cancer. Eur Urol 2013; 64(2):219-24.

105. Raza SJ, Wilson T, Peabody JO, et al. Long-term oncologic outcomes following robot-assisted radical cystectomy: results from the International Robotic Cystectomy Consortium. Eur Urol 2015 Oct;68(4): $721-8$.

106. Nguyen DP, Al Hussein Al Awamlh B, Wu X, et al. Recurrence patterns after open and robot-assisted radical cystectomy for bladder 
cancer. Eur Urol 2015 Sep;68(3):399-405. http://dx.doi.org/10.1016/ j.eururo.2015.02.003 PubMed PMID: 25709026.

107. Albisinni S, Fossion L, Oderda M, et al. Critical analysis of early recurrence after laparoscopic radical cystectomy in a large cohort by the ESUT. J Urol 2016 Jun;195(6):1710-7.

108. Collins JW, Hosseini A, Adding C, et al. Early recurrence patterns following totally intracorporeal robot-assisted radical cystectomy: results from the EAU robotic urology section (ERUS) scientific working group. Eur Urol 2016 Nov 2. http://dx.doi.org/10.1016/ j.eururo.2016.10.030 pii: S0302-2838(16)30744-8.

109. Znaor A, Lortet-Tieulent J, Laversanne M, Jemal A, Bray F. International variations and trends in renal cell carcinoma incidence and mortality. Eur Urol 2015 Mar;67(3):519-30.

110. Tsivian M, Rampersaud Jr EN, del Pilar Laguna Pes M, et al. Small renal mass biopsy - how, what and when: report from an international consensus panel. BJU Int 2014 Jun;113(6):854-63.

111. Volpe A. The role of active surveillance of small renal masses. Int $J$ Surg 2016 Dec;36(Pt C):518-24.

112. Yang G, Villalta JD, Meng MV, Whitson JM. Evolving practice patterns for the management of small renal masses in the USA. BJU Int 2012 Oct; $110(8): 1156-61$.

113. Ljungberg B, Bensalah K, Canfield S, et al. EAU guidelines on renal cell carcinoma: 2014 update. Eur Urol 2015 May;67(5):913-24.

114. Hadjipavlou M, Khan F, Fowler S, et al. Partial vs radical nephrectomy for T1 renal tumours: an analysis from the British Association of Urological Surgeons Nephrectomy Audit. BJU Int 2016 Jan; 117(1):62-71.

115. Alanee S, Nutt M, Moore A, et al. Partial nephrectomy for T2 renal masses: contemporary trends and oncologic efficacy. Int Urol Nephrol 2015 Jun;47(6):945-50.

116. Pierorazio PM, Johnson MH, Patel HD, et al. Management of renal masses and localized renal cancer: systematic review and meta-analysis. J Urol 2016;196:989-99.

117. Mir MC, Derweesh I, Porpiglia F, Zargar H, Mottrie A, Autorino R. Partial nephrectomy versus radical nephrectomy for clinical T1b and T2 renal tumors: a systematic review and meta-analysis of comparative studies. Eur Urol 2016 Sep 7. http://dx.doi.org/10.1016/j.eururo.2016.08.060 pii: S0302-2838(16)30533-4. [Epub ahead of print] Review. PubMed PMID: 27614693.

118. Van Poppel H, Da Pozzo L, Albrecht W, et al. A prospective, randomised EORTC intergroup phase 3 study comparing the oncologic outcome of elective nephron-sparing surgery and radical nephrectomy for low-stage renal cell carcinoma. Eur Urol 2011;59:543-52.

119. Scosyrev E, Messing EM, Sylvester R, et al. Renal function after nephron-sparing surgery versus radical nephrectomy: results from EORTC randomized trial 30904. Eur Urol 2014;65:372-7.

120. Patel HD, Mullins JK, Pierorazio PM, et al. Trends in renal surgery: robotic technology is associated with increased use of partial nephrectomy. J Urol 2013;189(4):1229-35.

121. Kaouk JH, Khalifeh A, Hillyer S, Haber GP, Stein RJ, Autorino R. Robot-assisted laparoscopic partial nephrectomy: step-by-step contemporary technique and surgical outcomes at a single highvolume institution. Eur Urol 2012;62(3):553-61.
122. Autorino R, Khalifeh A, Laydner H, et al. Robot-assisted partial nephrectomy (RAPN) for completely endophytic renal masses: a single institution experience. BJU Int 2014 May;113(5):762-8.

123. Eyraud R, Long JA, Snow-Lisy D, et al. Robot-assisted partial nephrectomy for hilar tumors: perioperative outcomes. Urology 2013;81(6): 1246-51.

124. Autorino R, Khalifeh A, Laydner H, et al. Repeat robot-assisted partial nephrectomy (RAPN): feasibility and early outcomes. BJU Int 2013;111(5):767-72.

125. Leow JJ, Heah NH, Chang SL, Chong YL, Png KS. Outcomes of robotic versus laparoscopic partial nephrectomy: an updated metaanalysis of 4,919 patients. J Urol 2016 Nov;196(5):1371-7.

126. Ghani KR, Sukumar S, Sammon JD, Rogers CG, Trinh QD, Menon M. Practice patterns and outcomes of open and minimally invasive partial nephrectomy since the introduction of robotic partial nephrectomy: results from the nationwide inpatient sample. J Urol 2014 Apr;191(4):907-12.

127. Rassweiler JJ, Klein J, Tschada A, Gözen AS. Laparoscopic retroperitoneal partial nephrectomy using an ergonomic chair: demonstration of technique and matched-pair analysis. BJU Int 2016 Aug 12. http:// dx.doi.org/10.1111/bju.13627 [Epub ahead of print].

128. Volpe A, Blute ML, Ficarra V, et al. Renal ischemia and function after partial nephrectomy: a collaborative review of the literature. Eur Urol 2015 Jul;68(1):61-74.

129. Simone G, Gill IS, Mottrie A, et al. Indications, techniques, outcomes, and limitations for minimally ischemic and off-clamp partial nephrectomy: a systematic review of the literature. Eur Urol 2015 Oct; 68(4):632-40.

130. Mir MC, Campbell RA, Sharma N, et al. Parenchymal volume preservation and ischemia during partial nephrectomy: functional and volumetric analysis. Urology 2013 Aug;82(2):263-8.

131. Serni S, Vittori G, Frizzi J, et al. Simple enucleation for the treatment of highly complex renal tumors: perioperative, functional and oncological results. Eur J Surg Oncol 2015;41(7):934-40.

132. Autorino R, Haber GP, White MA, Stein RJ, Kaouk JH. New developments in renal focal therapy. J Endourol 2010;24(5):665-72.

133. Zargar H, Atwell TD, Cadeddu JA, et al. Cryoablation for small renal masses: selection criteria, complications, and functional and oncologic results. Eur Urol 2016 Jan;69(1):116-28.

134. Kelly EF, Leveillee RJ. Image guided radiofrequency ablation for small renal masses. Int J Surg 2016 Dec;36(Pt C):525-32.

135. Cornelis FH, Marcelin C, Bernhard JC. Microwave ablation of renal tumors: a narrative review of technical considerations and clinical results. Diagn Interv Imaging 2016 Dec 20. http://dx.doi.org/10.1016/ j.diii.2016.12.002 pii: S2211-5684(16)30285-6. [Epub ahead of print].

136. Wagstaff PG, Buijs M, van den Bos W, et al. Irreversible electroporation: state of the art. Onco Targets Ther 2016 Apr 22;9:2437-46.

137. Beksac AT, Rivera-Sanfeliz G, Dufour CA, et al. Impact of tumor histology and grade on treatment success of percutaneous renal cryoablation. World J Urol 2016 Aug 2. http://dx.doi.org/10.1007/ s00345-016-1911-6 [Epub ahead of print]. 